Florida International University FIU Digital Commons

$7-2-2014$

\title{
Islam and Christianity: Comparing the Theory of Supersession Concerning Abraham
}

Mark Sweeney

Florida International University, marksweeney1988@gmail.com

DOI: $10.25148 /$ etd.FI14071181

Follow this and additional works at: https://digitalcommons.fiu.edu/etd

\section{Recommended Citation}

Sweeney, Mark, "Islam and Christianity: Comparing the Theory of Supersession Concerning Abraham" (2014). FIU Electronic Theses and Dissertations. 1557.

https://digitalcommons.fiu.edu/etd/1557 


\section{FLORIDA INTERNATIONAL UNIVERSITY}

Miami, Florida

\section{ISLAM AND CHRISTIANITY: COMPARING THE THEORY OF SUPERSESSION CONCERNING ABRAHAM}

A thesis submitted in partial fulfillment of

the requirements for the degree of

MASTER OF ARTS

in

RELIGIOUS STUDIES

by

Mark Sweeney 
To: Dean Kenneth G. Furton

College of Arts and Sciences

This thesis, written by Mark Sweeney, and entitled Islam and Christianity: Comparing the Theory of Suppersession Concerning Abraham, having been approved in respect to style and intellectual content, is referred to you for judgment.

We have read this thesis and recommend that it be approved.

Iqbal Akhtar

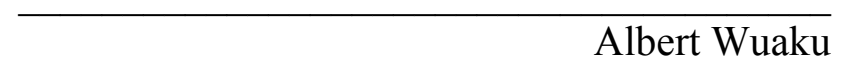

Erik Larson, Major Professor

Date of Defense: July 3, 2014

The thesis of Mark Sweeney is approved.

$\begin{array}{r}\text { Dean Kenneth G. Furton } \\ \text { College of Arts and Sciences } \\ \hline \begin{array}{r}\text { Dean Lakshmi N. Reddi } \\ \text { University Graduate School }\end{array}\end{array}$

Florida International University, 2014 


\section{ABSTRACT OF THE THESIS \\ ISLAM AND CHRISTIANITY: COMPARING THE THEORY OF SUPPERSESSION CONCERNING ABRAHAM}

by

Mark Sweeney

Florida International University, 2014

Miami, Florida

Professor Erik Larson, Major Professor

Supersession is the theory of one idea supplanting the other. In both Christianity and Islam, this idea is commonplace. In Christianity, the message of Jesus creates a New Covenant for both Jews and Gentiles, while in Islam, the revelation of Muhammad restores the original religion that God intended from the beginning.

Christianity and Islam both supersede Judaism in very similar ways. In regards to the use of Abraham in particular, each religion inherits him by appealing to Jewish scripture or their oral tradition, using him to prove their truth claims, and claiming that their religion is originally the religion of Abraham. 


\section{TABLE OF CONTENTS}

CHAPTER

PAGE

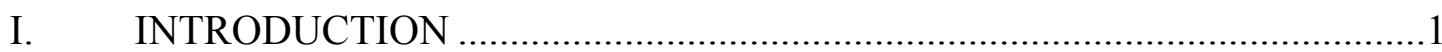

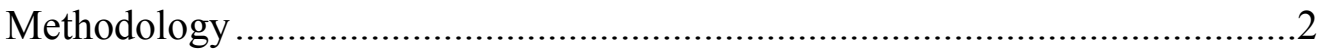

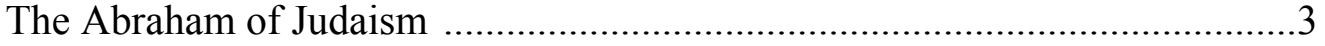

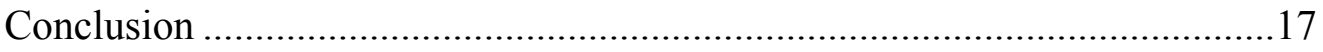

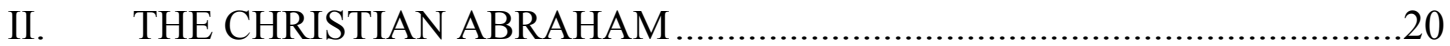

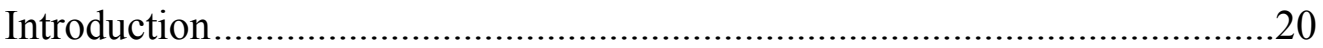

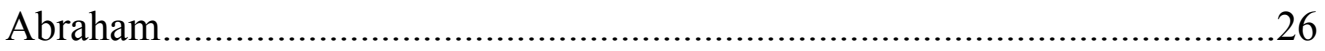

The True Descendants of Abraham .........................................................28

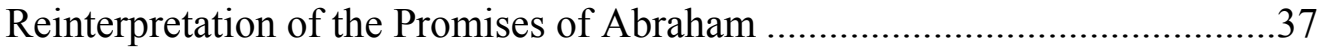

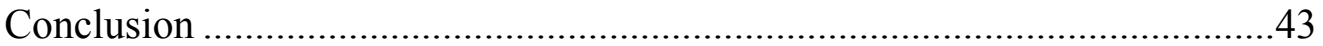

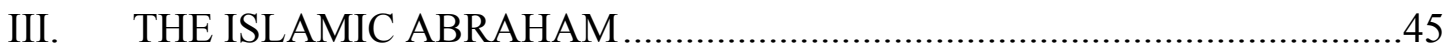

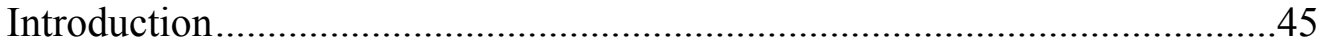

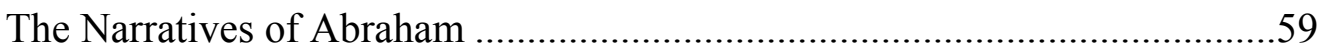

Abraham as the Embodiments of Muhammad's Message.............................61

Conclusion .....................................................................................64

IV. SAME ROADS TO THE SAME CONCLUSION ......................................66

Sharing Scripture with their Jewish Counterpart .......................................67

Using Abraham to Prove Truth Claims .................................................... 70

The Original Religion of Abraham .............................................................73

Implications and Future Research.......................................................73

V. Bibliography................................................ 75 


\section{INTRODUCTION}

Supersessionism signifies one faith being either replaced or supplanted by another one. It is a deeply sensitive term because it has often been used in a hardline way suggesting religious superiority over another. ${ }^{1}$ Islam and Christianity have a very rich dialogue concerning Judaism through the lens of supersession, both confirming and superseding the Jewish faith. It is important to note that the term supersession does not appear within the Bible or the Quran; however, this analytical term can still be applied to certain doctrines like who are the actual descendants of Abraham. The theory of supersessionism, if applied to Christianity, as well as Islam, refers to either the fulfilling of Judaism in a significant way or a returning to a primordial religion.

Discussing every argument of the supersession discourse is beyond the scope of the present work; therefore, the purpose of the thesis is to focus on a major argument found within the dialogue of both Christianity and Islam concerning Judaism. The argument revolves around Abraham because he has a major importance to each faith: they each claim to be the true heirs of this patriarch. The present project will explore this claim as both, Christianity and Islam, share chief similarities concerning the discussion about Judaism in regards to Abraham.

The significance of this work is twofold. First it will show something that is not often presented in scholarship: a comparison of supersession within the traditions of

\footnotetext{
${ }^{1}$ This project will be discussing supersession concerning Christianity and Islam in regards to Judaism; however, the focus is not on the 'extreme' use of this term. The extreme use is in regards to one religion being inferior to another. Though these ideas are found in writings of both Christian and Muslim authors, the project will not discuss this radical usage. Consequently, the highlight of this present work is simply on the idea that one religion 'superseded' or 'supplanted' another, meaning that one faith is closer to the truer intention/revelation of God.
} 
Christianity and Islam. There is already a plethora of information on supersession in academia involving the fields of Christianity and Islam; however, these topics tend to only be discussed in separate circles. Thus, the second significant aspect that will be revealed in this thesis is the importance of bringing these two fields together. Comparing these two traditions will show important similarities within the religions' themselves; namely, how they deal with a specific idea in Judaism: heritage of Abraham. Comparison opens the door to future projects of comparisons that can reveal more similarities within these religions. It is important for not only academia, but also the populace, to know that these religions are more like siblings than foreigners.

\section{Methodology}

The primary method that is used in the present thesis is a textual analysis of the Qur'an and the New Testament because these are the sacred sources of Islam and Christianity, and there will also be scholarly opinions that analyze these sacred texts. The project will primarily be concerned with the heritage of Abraham in these traditions. There are a few research questions that the project will be investigating. The first question revolves around how each tradition begins to discuss their relationship with Abraham. For instance, the Qur'an; unlike the New Testament, retells the narrative of Abraham. The story found in the Qur'an actually has many parallels to the one located in Genesis, but the important difference is the provision of a new historical background of Abraham. It goes through key events that portray his dedication to God, like his smashing of idols (Sura 21:58) which is not found in the book of Genesis. Within the Qur'an's perspective, Abraham's religion resembles Islam and not Judaism. 
Another question that will be explored in this research is about the possibility of similarities in how Christianity and Islam prove their perspective. Each tradition uses the strategy of proof texting which means they go back to the original story of Abraham. Christianity will refer to the story of Genesis; however, Islam will discuss a narrative that parallels this story. The purpose of the proof texting is to show that supersessionism within Christianity and Islam has similar approaches; however, it also reveals that Christianity and Islam have parallel conclusions. Within each tradition, the idea of being the original bearers of Abraham's religion, as well as the idea of superseding his religion, will be shown.

\section{The Abraham of Judaism}

Abraham is one of the most important figures in Judaism and he is often called Avraham Avinu (Our Father Abraham). As the title suggests, he is considered the father of the Jewish people; however, he is not simply their biological progenitor, he is also the founder of the Jewish faith itself. Jon D. Levenson states Abraham as: “...the first Jew, and the man whose life in some mysterious way pre-enacts the experience of the Jewish people, who are his descendants and who are to walk in the trails he blazed" (Levenson 4). He pre-enacted the experience of the Jewish people primarily by rediscovering the worship of the one true God. It is important to note though that Abraham is a very complex individual within Judaism for two reasons. The first reason is that it is somewhat a mystery in scholarship as to why he holds such significance in the Jewish faith. He is generally considered the father of the Jewish religion, but he distinguishes himself radically from other monotheistic religions founders like Jesus or Muhammad (Levenson 4). Concerning Christianity and Islam, their religious founders are sought to be emulated; 
however, Abraham is not. Abraham did not share the same practices or observances that Jews of antiquity or modernity held. He did not even follow the kosher laws. From a legalistic standpoint, Moses or even the Rabbis of the Midrash, seem to be better heralds of Judaism than Abraham.

The second reason that Abraham finds complexity is a result of the simple fact that his narrative is ancient. He has been considered a patriarch of the faith for a few thousand years. It is hard to date exactly when Abraham became esteemed so highly because there is a lack of written record of the ancient Israelite people. However, he has at least been a cornerstone for the faith since the time of Alexander the Great (Feiler 124). Since Abraham is such an ancient character, it is only natural that throughout the history of the Jewish people, he would become entangled in numerous theologies and legends. There are expositions on Abraham which are found in the Midrash: ancient commentaries on Hebrew scripture. ${ }^{2}$ Within these writings are numerous stories and embellishments, for instance, there is one legend of Abraham which he refused to die during the end of his life. The archangel Michael came to him to take his soul back to God but Abraham denied him and instead went on a journey through the realms of Heaven and earth (Guizberg 304). There are even stories and beliefs in Judaism that give Abraham a semi divine status. It is beyond the scope of this work to 'detangle' all the doctrines and legends of Abraham found in the Midrash and other writings of antiquity. This project will focus on chapters $12-25$ of Genesis. ${ }^{3}$ It is also important to note, that

\footnotetext{
${ }^{2}$ The Genesis Rabbah, which is the Midrash on the Book of Genesis, is important in regards to the analysis of Abraham especially concerning Islam. This work was written and edited in the beginning of the fifth century C.E. and therefore predates Muhammad (Herr and Wald 449).
} 
regardless of the period of history, whether ancient or modern, there are three major themes that are commonly accepted in Judaism which concern God's promise and covenants to Abraham and there realization, Abraham's faith, and the status of him being an intermediary of God.

\section{The Promises of God}

The promise that God gives to Abraham becomes the foundation of his significance. It is the makeup of the systematic belief that revolves around Abraham's importance. Essentially, there is one promise that God gives to Abraham; however, there are two separate covenants that God makes with him. The promise is given in Genesis 12 and the story of Abraham actually begins with it. After he heard it, he leaves his home (at the ripe age of 75) with his friends and most of his family. He does not leave his home completely alone; he takes his nephew Lot as well as his barren wife Sarai (later God names her Sarah). Thus, he begins his journey while intently listening to the divine voice. The promise that God gave to Abraham is arguably the most important element of the Abrahamic narrative. His account found in Genesis 12 begins with the promise from God that states:

Now the Lord said to Abram, "Go from your country and your kindred and your father's house to the land that I will show you. And I will make of you a great nation, and I will bless you and make your name great, so that you will be a blessing. I will bless those who bless you, and him who dishonors you I will curse, and in you all the families of the earth shall be blessed."(Gen 12:1-3) ${ }^{4}$

\footnotetext{
${ }^{3}$ Also, in chapter 3, The Islamic Abraham, it will be shown that Islam also has interesting parallels concerning their narrative traditions in regards to their Jewish counterpart.

${ }^{4}$ All verses of the Bible are derived from the English Standard Version (ESV)
} 
The promise is extremely significant in Judaism in at least two major ways. The first reason is that God choose Abram (Abraham) to receive a blessing. God told him that he would not only make Abram's name great, but a great nation will stem from him. Generally, this is interpreted in Judaism as God's choosiness of the decedents of Abraham: the Jewish people. Levenson claims that this idea of divine election might have been a theology that was developed much later (Levenson 22). However, the idea of election becomes essential to the supersession discourse that will be presented in the present project. Be that as it may, the idea of divine election finds significance in Judaism because it was such an unlikely promise; God did not choose Abram because he was genetically superior to those around him; on the contrary, he was hoary and his wife was barren. He also belonged to no tribe of importance. Therefore, God chose Abram and his descendants to be the recipients of a special divine favor.

The second reason this promise is significant is because Abraham is not only going to receive a blessing, but he will become one: "and in you all the families of the earth shall be blessed." The verse finds great importance especially concerning how the Christians used it to prove their heritage to Abraham; however, it is highly debated. ${ }^{5}$ In most Christian Bibles, the word that is used is in; yet, in in the New Jewish Publication Society's translation it reads: "And all the families of the earth will bless themselves by you." There are three different ideas of what this means in Judaism that should be discussed. The first idea is that in Jewish exegesis, Abraham will become a byword word

\footnotetext{
${ }^{5}$ The Christian interpretation of this verse will be explained more in-depth in the second chapter of this project.

${ }^{6}$ Emphasis added.
} 
for blessing (Moberly 152). Moberly also states, that throughout the Hebrew Bible, it was common for people to bless or curse others by using a name. For instance in Jerimiah 29:22 there is a curse by the names of Zedekiah and Ahab. ${ }^{7}$ In other words, Abraham is a word that, just by being referenced to, can cause a blessing from God (Moberly 153).

The second idea concerning the blessing that the name of Abraham brings is from the merit that he earned from God. Throughout the patriarch's narrative in Genesis, it becomes clear that Abraham follows God with an intense devotion and faith which will be described later. According to one Midrashim interpretation, his deeds earned merit that would be passed down to all of his descendants through the irrevocable promise found in Genesis 12. The promise is irrevocable because it has no obligations for Abraham to follow except leaving his land. However, the merit benefits not only the actual descendants but "all the families of the earth." This particular clause again becomes important in the supersession discourse of this work; however, according to Judaism, there are different explanations for how the 'families of the earth' become blessed. One process of becoming a blessing is by the emulation of Abraham. According to Rashi's commentary, the 'families of the earth' can emulate Abraham and become blessed because the patriarch's ways were righteous; however, according to Moberly, the interpretation can go to an extreme (Moberly 155). The extreme interpretation that can be found in both Christian and Jewish scholarship is that non-Children of Abraham can also claim the promise and favor of God. According to mainstream Jewish interpretation, Genesis $12: 3 \mathrm{~b}$ was never meant to ascertain that 'other families', by either emulating or

\footnotetext{
${ }^{7}$ Jerimiah 29:22 states: "Because of them this curse shall be used by all the exiles from Judah in Babylon: "The LORD make you like Zedekiah and Ahab, whom the king of Babylon roasted in the fire,"
} 
using the name of Abraham, will be bestowed with the same favor that Abraham's descendants were promised. On the contrary, it was only meant that other peoples who did not come from the lineage of Abraham, will attempt to emulate the patriarch.

The promise of Genesis 12 was not fulfilled immediately. On the contrary, Abraham continued to wander from place to place. He found himself in Egypt in the presence of the Pharaoh and he also explored the region of Hebron (Genesis 13:18). Over the course of this period Abraham became very wealthy; however, he was still childless and confused as to how God was going to fulfill his promise. Levenson makes an interesting observation concerning who Abraham thought would be the inheritor of his legacy. God never stated in Genesis 12 as to whom his descendants would stem from. Thus Levenson suggests, that prior to his actual son, Abraham might have believed it was Lot (his nephew) or his steward Eliezer of Damascus (Levenson 41). Lot was Abraham's orphaned nephew who was treated like a son; in Judaism a nephew could have been a candidate to be an heir; however, there was a dispute between Abraham's followers and Lot's. At that moment, they each decided to go their separate ways. Eventually, Abraham turned to God for answers, and it is here that Eliezer was also deemed as unfit to be the inheritor (Genesis 15:1-4).

Genesis 15 is very significant in Judaism because it is at this point that God not only confirms his promise found in Genesis 12, but he makes a covenant with Abraham. According to Genesis, Abraham began to plead with God petitioning him concerning the status of the promise. He states "O Lord GOD, what will you give me, for I continue childless, and the heir of my house is Eliezer of Damascus?" (Gen 15:2). It appears that Abraham began to have doubt; however, this doubt was short lived because God 
immediately responded stating "This man shall not be your heir; your very own son shall be your heir" (Gen 15:4). God proceeds by restating the promise found in chapter 12 telling him that his descendants shall be without number. They will also be given a land to call their own as well. God then makes a covenant with Abraham to confirm the word he gave. It is interesting to note that like the promise found in Genesis 12, there is nothing that Abraham has to do. This covenant is to ratify God's commitment. It is irrevocable; all responsibility falls on God to fulfill his oath.

The covenant given to Abraham highlights two significant observances that Jews hold concerning their patriarch. The first is that Abraham becomes a paradigm of faith. God told Abraham that he is going to do something highly improbable: make Abraham a great nation, give him a son (remember he is over 75 years old), and present him with his own territory to call his own. In Genesis 15:6 it states "And he believed in the LORD, and he counted it to him as righteousness." 8 The second observance is inferred by another prospect of the covenant found in chapter 15 of Genesis. In the same breathe that God uses to reconfirm the promise of Genesis 12, he also states in verses 15-16 that his offspring will not inherit land immediately; they will become slaves and oppressed for four hundred years. Though Abraham will never experience this, he gets a glimpse of what the future has in store for his people. This observation does not go unnoticed in Jewish exegesis. Thus, Abraham now becomes "a symbol of God's fulfillment of his irrevocable promise despite the horrific and seemingly interminable parenthesis in history." (Levenson 45). In other words, Abraham becomes a name that promotes remembrance of God's irrevocable promise.

\footnotetext{
${ }^{8}$ This verse becomes very important in the Christian discourse.
} 
There is a curious observation concerning this covenant that is found in Genesis 16. During this period of time, polygamy was acceptable. In the covenant of chapter 15 , God does not state who will bare him a son. Sarai is very old and has been barren throughout the narrative of Abraham; however, in Genesis 16 she suggests that they become more proactive in the process of fulfilling the promise. She advises Abraham to consummate with her servant Hagar. According to Levenson, "the basis for this idea that an infertile woman could become a mother through her slave probably lies in the legal institutions of ancient Israel" (Levenson 47). Consequently, Abraham agrees to allow Hagar to become a surrogate mother. She bore him a son who would be called Ishmael. This becomes very important in Islam because Ishmael is believed to be the rightful heir of Abraham and is considered the father of the Arabs. ${ }^{9}$ After the birth of Ishmael though, there becomes rivalry between Sarai and Hagar. Sarai is jealous and wants to punish her which Abraham allows, but God, on the other hand, encourages Hagar to submit to Sarai. She was comforted by an Angel of the LORD and obeyed him.

The significance of this episode of birth, envy, and obedience, is that it brings to the fore the second and final covenant that God makes with Abraham. In Genesis 17, God appears to Abraham and restates his promises once again. He tells him that he will be a father of a multitude of nations; nevertheless, God adds a few details. Part of the covenant is that now God will become the God of Abraham as well as the God to his descendants. They will become his people, but this is not an irrevocable promise. Unlike the first promise and covenant, Abraham must circumcise himself as a sign of this new

\footnotetext{
${ }^{9}$ The narrative concerning Abraham and Ishmael is very significant within Islam. It is through him that Muslims claim heritage to Abraham. This will be further discussed in the chapter concerning Islam and Abraham.
} 
and 'everlasting covenant'. In other words, this new covenant will be one that goes on through the coming ages. And "any uncircumcised male who is not circumcised in the flesh of his foreskin shall be cut off from his people; he has broken my covenant" (Genesis 17:14). Another substantial element is that this covenant is not going to be through Hagar's son Ishmael, but through Sarai. Sarai will be blessed with a child and it is through his line that the covenant will be passed down. Ishmael, even though he becomes circumcised, is not the harbinger of this covenant; however, God continues to be faithful with the original promise that he gave in Genesis 12.

"As for Ishmael, I have heard you; behold, I have blessed him and will make him fruitful and multiply him greatly. He shall father twelve princes, and I will make him into a great nation." (Genesis 17:20)

Eventually, within a year, the promised son was born who would become known as Isaac. Through him and his son Jacob, the promise of God became a reality and the people of Israel appeared on the pages of history. These promises and covenants reveal that the descendent of Abraham are chosen people, blessed by God by an irrevocable, yet unlikely promise.

\section{Faith of Abraham}

Abraham's significance derives heavily on the promises and covenants that God makes with this patriarch; however, there is also another aspect which sheds more light on Abraham's importance: his faith. As briefly noted earlier, Abraham's faith becomes a key element within Christianity as well as Islam. He becomes the embodiment of a 'true' believer. Though the Christian and Islamic perspective will be described in detail later, this same idea is also found within Jewish exegesis as well. Throughout the narrative of the patriarch, Abraham is constantly depicted as seeking and following the voice and will 
of God. If the promises indicate the blessings that God will bestow on Abraham and his descendants, the faith of Abraham indicates his response to God's promises.

There are essentially two different elements of Abraham's faith within his narrative found in Genesis: his confidence that God will remain true to his word, and Abraham's obedience. The first prospect of his faith can be seen in his reactions to the promise of God. The first prospect is noted in Genesis 15. As stated earlier, God's promise was not fulfilled immediately after it was declared in chapter 12 , but in chapter 15, it seems that Abraham began to doubt; consequently, he appealed to God for answers. When his pleas were resolved with not only a reaffirmation but a covenant, he "believed in the LORD and it was counted to him as righteousness" (Genesis 15:6). The belief that Abraham had was also the confidence in God's existence as well. Jeffery S. Siker states that the writings of early Judaism in which were before the Midrash attest to this. In the Testament of Levi, the text tells of how Abraham was persecuted and this was because of his faith in God. Abraham came from a land of idols and even his father participated in the creation of their paraphernalia, yet Abraham did not bend his knee and continued to believe (Siker 22).

The most important aspect of Abraham's faith in Judaism was his faithfulness to God: his obedience. There are numerous stories of Abraham's obedience, but arguably the most notable one is the binding of Isaac, which is also called the Aqedah. It is essential to note that this story will also find prominence in Christianity as well as in Islam at least to some extent. Within Judaism however, this story has a multitude of interpretations concerning virtually every aspect of the narrative; they range from the ideas revolving around the actual binding of Isaac to the ram that was sacrificed. It is 
beyond the confines of this introduction to delve into these ideas and theologies; therefore, in the midst of these countless discourses there is the theme of Abraham's faithfulness based on the story found in Genesis 22 .

According to the story of the Aqedah, God decided to put Abraham to the test. He told the patriarch to take his son to a mountain that was unspecified, and offer him up as a sacrifice to God. Frequently in Judaism, this trial is seen as a test of Abraham's faith in God's promise. It is notable to mention that, according to the Torah, Abraham did not hesitate to obey God (Levenson 70). There was absolutely no questioning on the part of the patriarch. The story continues with Abraham finding the place that God specifies for the sacrifice; he creates an altar, binds Isaac, and lays him on it. In the moment that he is about to slaughter his son, an angel of the LORD called to him and told him to cease. (Genesis 22:9-12). Afterwards the Angel of the LORD states:

“...because you have done this and have not withheld your son, your only son, I will surely bless you and I will surly multiply your offspring as the stars of heaven and as the sand that is on the sea shore. And your offspring shall possess the gate of his enemies, and in your offspring shall all the nations of the earth be blessed, because you have obeyed my voice" (Genesis 22:16-19).

Frequently in Judaism, this trial is seen as a test of Abraham's faith in God's promise. It is notable to mention that, according to the Torah, Abraham did not hesitate to obey God (Levenson 70). Abraham loved his son dearly (Gen 22:2) and in retrospect of this chapter, Isaac represents everything God promised to Abraham; he was the embodiment of that promise. Through Isaac, Abraham's legacy and descendants would come forth, the promise of land would be given, and nations would see and revere him. The choice that Abraham had to suffer is unimaginable because he had to elevate his love and devotion of God over the love of his son who signifies everything that God had sworn. However, in 
the Aqedah, "the alternative is apostasy-in the form, however, not the defection to another god but of withholding his beloved son from the God who gave him..." (Levenson 81). Thus, this would elevate Abraham's personal self-interest over obedience to the God to whom he owes everything.

Within Judaism, the faith that Abraham has in God is legendary. Throughout chapter 22, as well as the rest of his narrative, Abraham continues to not only trust in God, but obey him in every circumstance. Though there are instances where he seems to take matters in his own hands, like having a son through Hagar, he always comes back to God and follows the plan that He set for him. When God speaks, Abraham listens instantly. Throughout the history of Judaism, from the time of the Second Temple to modernity, the Jewish people have seen his faith as something to be emulated.

\section{Abraham as an Intermediary}

The final aspect concerning Abraham's importance in Judaism is that Abraham is often perceived as an intermediary between God and humanity. Throughout the narrative of this patriarch, it is not only Abraham's faith or the promises that are given to him, but it is his unique relationship with the Divine that is very important within Judaism. The relationship that he has with God seems to be very personal and unique within the story of Genesis as a whole because God not only listens to what he says, but he also responds to his requests.

There are many instances of God responding to Abraham. The first one to be noted was discussed earlier. When Abraham beseeched God about his promise in Genesis 15 , God responded and had a conversation with him. It is not only this conversation, but it is the unique covenant that God made with him because, according to Levenson, God 
curses himself if he fails to uphold his part (Levenson 44). The idea is drawn from a parallel with Jeremiah 34:17-22. The process of the covenant in both Genesis 15 and Jeremiah 34 is the passing between the two halves of a slaughtered calf. Whichever party passes the calf is obliged to follow through with their oath; however, in Genesis 15, it is God who passes in between the halves of the calf (Walvoord). Therefore, God is declaring to Abraham that he will curse himself if he does not follow through with this promise. This reveals such a unique and significant relationship that God has with Abraham.

Another narrative in Genesis shows a different aspect concerning Abraham's relationship with God; namely, the characteristic of him being an intermediary between humanity and the Divine. As noted earlier, in Genesis 13, Lot and Abraham separate because there is tension and quarrels among each of their affiliated parties. In Genesis 18, 'the LORD' appears to Abraham and tells him about the wrath he is going to pour out on the city of Sodom which will result in its destruction. ${ }^{10}$ Sodom is known in Jewish scripture as a wicked and immoral place; however, at the time of the LORD's proclamation, this is where Lot was settling in. Abraham begins to intercede for this city. He asks the LORD "Will you indeed sweep the righteous with the wicked?" (Genesis 18:23). Following this question, the LORD begins to state that he will spare the whole city if there is even one righteous person. The dialogue is extremely significant because it seems that Abraham changes the mind of the LORD or in the very least, offers him some sort of counsel that was heeded.

\footnotetext{
${ }^{10}$ The identity of what 'the LORD' refers to is highly contested. In Christianity, it is commonly asserted that this was the Divine himself; however, Judaism does not hold this view. Also, it is interesting to note that in Islam this dilemma is altogether non-existent. In Islam, the Divine is not visiting Abraham but Angels. This will be discussed in greater detail during the third chapter of this project.
} 
These examples also reveal a priestly characteristic that is found within Abraham. As noted above, God often appears to Abraham and he responds to his requests as well. Also within the narrative of Genesis, Abraham builds numerous altars to God and offers sacrifices on them. The Aqedah is a prime example of this; Abraham was going to sacrifice his son, but when that did not commence as perceived, Abraham sacrificed a ram instead. Though this is a common theme in Genesis, this point is not often overlooked in Jewish writings of antiquity. Jeffery S. Siker points out that the Testament of Levi has Abraham as actually teaching Levi how to make certain offerings (Siker 26). Abraham is thus seen as one of the first priests in Judaism.

\section{Final thoughts on Abraham in Judaism}

As seen above, Abraham has a very unique status in Judaism. It is difficult to describe all the opinions and ideas that surround him because there is a multitude of voices throughout every age of history; however, it is possible to develop and discuss at least some generalities of Abraham that is found in the majority of Judaism. This is made possible by investigating the book of Genesis itself. Within these scriptures, Abraham clearly has a unique relationship with the Divine. God calls Abraham and gives him an unlikely promise of descendants, land, and blessing. Abraham was not unique biologically nor did he come from a special tribe; Abraham was an old man who listened to the voice of God. He believed and was faithful to every command that was given; this led him from his home to eventually a mountain where he intended to sacrifice his son. Abraham became the father of not only a people, but a religion. In retrospect of his story, it is actually not surprising to see why Abraham is often referred to. According to the text, he was a man of God that did not falter. 


\section{Conclusion}

Therefore, in light of the Jewish conception of Abraham, it is not unexpected that Christianity and Islam both attempt to trace their origins to him as well. In observing Genesis, Abraham is a founder of the Jewish faith. He was a faithful servant of God and the promises given to him were powerful. Thus, within the scriptures of both Christianity and Islam, there is an attempt to claim heritage to this patriarch; Abraham has repeatedly been a major topic within a multitude of polemics of these religions. The reason why he is so significant in these two traditions is that God chose Abraham's descendants' to receive His promises. The claim of Abrahamic descent is essentially a claim to be the Divine's chosen people.

Concerning the New Testament, there are numerous verses that describe who Abraham really was and his significance. The significance is not found in being a physical descendent of Abraham; on the contrary, there seems to be a negative opinion on claiming physical heritage with Abraham. In the Gospel of Mathew, after calling Jewish leaders 'a brood of vipers', John the Baptist states "And do not presume to say to yourselves, 'We have Abraham as our father,' for I tell you, God is able from these stones to rise up children for Abraham" (Matt 3:9). In Christianity, the significance of Abraham revolves around, not in his obedience, but his faith. This message is particularly clear in the letters attributed to Paul. In Romans 4, Paul discusses that the significance of Abraham is that he was justified to God by faith and not by his bloodline or works. The same faith that justified Abraham can justify all men; therefore, in a way, the Christians are practicing the original religion of Abraham. However, at the same time, there are other areas in the New Testament that argue about an establishment of a New Covenant 
that was created through Jesus. There was no longer a need to practice the traditional laws of the Jews; hence, Christians often highlighted that Abraham did not follow the customs as the Jews of their time followed. Thus, as it will be shown later, Christians highlight different aspects of Abraham, and it is by these that their claim becomes justified in their eyes.

The selected passages, which deal specifically with Abraham, from the Qur'an, will reveal a similar approach that their Christian counterpart took concerning the discussion on the patriarch. It is not that being the physical descendent of Abraham is not important, because there are verses in the Qur'an that discuss this; however, the significance is that Abraham is a precursor to Muhammad. Surah 2:135 states "They say, 'Become Jews or Christians, and you will be rightly guided.' Say [Prophet], 'No, [ours is] the religion of Abraham, the upright, who did not worship any god besides God." It is clear that in this verse Islam is equated with the religion of Abraham; consequently, there is a critique of Judaism that is often recalled. The Jewish message has been corrupted and the Jews no longer follow the way that God intended. Thus, Islam in a sense is a return to the pure monotheism of Abraham which is the essence of the supersession discourse within the religion. It is important to notice that though the Qur'an discusses a lot about Abraham's actions, Muslims do not try to imitate him but Muhammad. It is the way of the final prophet that is emulated. The Islamic perspective on Abraham, as explained in the Qur'an and the Sunnah, is that of Islam being a return to the true religion of Abraham through Muhammad who corrected the intentional deviation from Abraham's faith by the Christians and Jews. Therefore, in regards to both Christianity and Islam, there is an 
echoing of superessionism even though, as stated earlier, the term does not appear in either of their sacred scriptures. 


\section{Introduction}

\section{THE CHRISTIAN ABRAHAM}

As it has been briefly noted, Abraham has a paramount status within Judaism; consequently, it is not surprising that Abraham had a prestigious honor within Christianity as well. Before discussing the status of Abraham in Christianity, it is important to briefly discuss Jewish and Christian relations after the claimed death and resurrection of Jesus took place. When Christianity developed, it was seen as an offshoot of Judaism. Remember, as stated earlier in chapter 1, Judaism was not monolithic. Just as there is a plethora of opinions and interpretations on Hebrew Scripture and theology in the contemporary era, there was the same situation during the $2^{\text {nd }}$ Temple Period. Judaism had numerous parties that were vying for authority during antiquity. The leaders of the temple were the Sadducees who were the priestly class; however, there were also the Pharisees, who were considered the leaders of the people, the Zealots, who desired to break the yoke of the oppressive Romans, and the Essences, who isolated themselves at Qumran to maintain purity before the Most High (Schiffman 74).

According to the New Testament, the first instance that the term 'Christian' was used is found in Acts 11:26. It was a title given to the followers of Jesus located in Antioch; however the identity of this group is unknown. There are virtually no clues as to whether the group were Jewish Christians, Gentile Christians, or non-Christians (Keener). However, there is also another term that followers of Jesus were labeled as: the Nazarenes. The term is found in Acts 2:22 and according to F. F. Bruce, it was most likely used as a designation for Jewish Christians from a very early date. The term derives from the word Notrim which, in the Talmud, was used to refer to Jesus and 
Christians. It also has a link to Isa 11:1 with a messianic branch called (netzer) (Bruce 440-41).

The name of Jesus's followers is not the only clue in regards to the pressing concern, the relations between Jews and the Christians. ${ }^{11}$ It is also argued that the majority of the teachings as well as the practices of Jesus and his disciples are also similar to rabbinical discourses and traditions (Herford 187). ${ }^{12}$ For instance, Paul's idea about the lack of necessity for circumcision and other significant Jewish traditions was not an idea that he originated. There were also sects and rabbis who had the same view point as well. Through the ministry of Jesus as well as his apostles, there appears to at first be an emphasis on the Jews themselves. Most of the disciples that followed Jesus were Jews and some of them were even Jewish leaders (Wilson 41). Even after Jesus' death, the apostles directed their attention initially to the Jews. Thus, the beginning of 'Christianity' was of Jewish origin. Throughout the Gospels as well as the book of Acts, Jesus and the disciples not only worshiped in the temple with the Jews, but they also were given numerous opportunities to teach within the synagogue. Acts 13:15 states: "After the reading from the Law and the Prophets, the rulers of the synagogue sent a message to them (Paul and Barnabas), saying, 'Brothers, if you have any word of encouragement for the people, say it."' Therefore, the 'Christian' movement appears to have originally been a Jewish one (Wilson 42).

\footnotetext{
${ }^{11}$ During the rest of this thesis, when the term Christian is used it refers generally to followers of Jesus. If there is a need to specify between Jew or Gentile Christian then it will be noted as well.

${ }^{12}$ The exact percentage of parallels and similarities are debatable; however, Herford estimates around $90 \%$ of Jesus' teachings can find a parallel to rabbinic Judaism.
} 
Though the New Testament shows the Jewishness of the Jesus movement, it also reveals an element that directly relates to the eventual inheritance of Abraham in Christianity, debates and disagreements found amongst the Christian believers and the Jews. It is important to emphasize that this issue is very complex and it is often over simplified. Even though it is beyond the scope of this present work to go into the schism in depth, it is significant to give a context in which Abraham was discussed (Hare 1). These disagreements began on a theological level and range from many different topics: the true nature of Jesus, law observance, and gentile inclusion. The last two topics can be discussed together.

The split between Jews and Christians began mostly on a theological framework. In the Christian perspective, the identity of Jesus is very revolutionary for the Jewish believer. It is one thing to claim messiahship, but another thing all together to claim divinity. According to Geza Vermes, followers of Jesus "transformed this lover of God into an object of worship himself..." (Vermes 13). In other words, the Jewish followers of Jesus did not just see him as a man, but as both God and man (Wilson 54). The idea also relates to the unique relationship that Jesus had with God. In Mark 14:36, Jesus calls God $A b b a$ which means 'my father'; however, according to Joachim Jermias, no one in Judaism would refer to God in such a way (Jeremias 20). It is like calling God 'Daddy' which is a term that would be too radically intimate. The last major theological conflict that is worth noting between the Jews and the followers of Jesus is the drastic reinterpretation of Jewish symbols that Jesus of Nazareth embodies. Jesus subordinated many of the central symbols of Judaism to himself, for instance, Jesus became the 
Temple, and the atoning sacrifice for Israel (Hare 5). Claiming these symbols essentially represents a claim to divinity.

Jewish and Christian relations also were tense concerning the ideas of law observance and Gentile inclusion as well. Though these two ideas will be described in greater detail when the patriarch Abraham is analyzed, it is significant to introduce the idea. Since the time of Jesus, there has always been a tension between the Jews and Jesus' followers concerning the law and the Gentiles. Regarding the law, many of Jesus' own discourses seem to highlight the friction between the two parties. One such stress is found involving what is permissible for an individual to do on the Sabbath. Jesus was known as a miracle worker in the New Testament; however, there are numerous instances where he does these on the Sabbath. For instance in both Mark 3 and Luke 13 Jesus is found healing two different crippled people within the temple itself. Consequently, because of these actions, there are numerous arguments between Jesus and the religious leaders' about doing good works on the Sabbath. The law observance idea also closely revolves around Gentile inclusion. In Judaism, when a Gentile converted, he was known as a proselyte. For this individual to be in the complete fold of Judaism, he had to "observe all the precepts that bind Jews" (Rabinoqitz and David 588). One of these precepts included circumcision; however, there were individuals who did not convert completely. The New Testament calls these individuals 'God-fearers', and according to Wilson, "these individuals were Gentiles who followed certain Jewish religious practices but stopped short of the circumcision required of all full proselytes" (Wilson 46). ${ }^{13}$ After

\footnotetext{
${ }^{13}$ There are a few stories of 'God-fearers' that are found in the New Testament. One important individual was a centurion that wished for Jesus to heal his servant (Luke 7). According to the text, his faith was so great that Jesus praised him by saying "I tell you, not even in Israel have I found such faith." Another
} 
the council of Jerusalem, which is recorded in Acts 15, it is declared that Gentile converts to the Jesus movement were not obliged to follow the Jewish law. Hence, it was not necessary for an individual to be circumcised in order to be considered a follower of Jesus. This belief had both a positive and a negative impact on the Jesus movement. On the one hand, Gentiles did begin to enter into the folds of the early church in abundance; however, on the other hand, this led to an increase in strain with relations to the other Jewish branches. The Jesus movement became more appealing for converts, a consequence of this is that it began to take away from the pool of potential proselytes from Judaism (Juster 138).

The final, and most significant, tension between Judaism and the followers of Jesus came about during the periods of the first and second Jewish revolts against Rome. ${ }^{14}$ The First Jewish Revolt was from C.E. 66-73, and it was centered in Jerusalem and Judea, and also other areas of the Jewish population. It was harshly put down by the Romans in the year 70; however, what is significant is that the Jewish Christians and the Gentile Christians did not take part in the conflict. Instead of fighting, they fled to the city of Pella which is located in the Jordan Valley. It became known as the 'Flight to Pella'

instance of a 'God-fearer' is found in Acts 10:2. In this specific instance, Cornelius worshiped God and followed certain Jewish practices. He became a follower of Jesus after Peter was led by the Holy Spirit to tell him about Jesus. After this instance, the gentiles were then brought into the fold of the Gospel of Jesus.

${ }^{14}$ There is another aspect which is highly debated concerning the final schism between the Jews and the followers of Jesus. It is known as the Birkat ha-Minim which in brief is often called the Heretic Benediction. The reason why I left this out is because it is still highly debated within academia. It is the twelfth Benediction of the set daily prayer commonly referred to as Shemoneh Esreh (or the Eighteen Benedictions) (Wilson 456). In brief it is a prayer about removing apostates from Judaism and condemning them. The Benediction explicitly refers to Christians (Wilson 62). The reason it is debatable is because there is a lack of evidence of an official 'excommunication' of Christians from the synagogue. As stated earlier, there were many religious parties that were competing for authority; therefore, it would appear that the banning of Jewish Christians varied from one place to another and it revolved around more by group outrage than by a formal ban (Hare 55-56). In context of the book of Acts, the majority of persecutions that befell Christians came from mob violence. 
(Wilson 76). The failure of Jewish Christians to support the movement against the Romans branded them in terms of disloyalty and treason. Since the Romans destroyed Jerusalem, which was a holy city where the temple of God was located, the removal of the Jewish Christians from Jerusalem began to lessen the close religious ties to Judaism.

Prior to the second revolt (which will be discussed below), there was another fundamental breaking between the synagogue and the Church which revolves around the Sabbath. The Church reorganized the holy day from Saturday to Sunday. The exact date is unsure, but the process began as early as 115 C.E. (Wilson 79). The Church's move to Sunday was a rejection of the very heart of Jewish experience-the rejection of the law. It was seen as leaving behind the Jewish past and from this time onward, it became very difficult for a Jew to consider the Christian message in any seriousness. According to the historian Jules Isaac, "The Jewish rejection of Christ was triggered by the Christian rejection of the Law... The rejection of the Law was enough; to ask the Jewish people that they accept this rejection was like asking them to tear out their heart. History records no example of such collective suicide" (Doukhan 25).

The Second Jewish Revolt (132-135 BCE) was the final parting between the Jews and the Christians (Richardson 36). The revolt started when Bar Kokhba was claimed to be the messiah of Israel. Hundreds of Jewish villages joined him in a bitter struggle against the Romans and more than half a million Jews perished in this struggle. Another result of the war was the total destruction of Jerusalem and Emperor Hadrian building a temple to Jupiter on the site of the Temple (Schoville 312). The Jewish Christians had the same response to the fighting as they did during the First Jewish Revolt; they refused to 
fight. One major factor was that if they committed to the cause of Bar Kokhba, it meant virtually denying the messiahship of Jesus (Jocz 71).

The historical relationship between the Jews and Christians shows the strains between the two groups of believers. This is the context where Abraham began to be discussed. Slowly, as it will be shown below, throughout the course of this time period, the idea of Christianity superseding Judaism began to take root. The message, and even the figure of Jesus, began to be seen as a fulfillment of the Abrahamic promise. It is not only this, but Abraham was also used in such a way that suggested the Christians were more Abrahamic then their Jewish counterparts. Therefore, it is impossible to properly understand the use of Abraham in the Christian context without at least a prior familiarity with the history of the differing groups. Thus, Abraham becomes a focal point for Christians in regards to understanding their faith and critiquing their Jewish siblings.

\section{Abraham}

The historical relationship between both Christianity and Judaism is rich and plentiful. It is very difficult to develop an analysis of the relations between the two religious ideas without falling into the snare of oversimplification. However, the background that was explained above shows the deep interactions as well as schisms between both Judaism and the Jesus movement. As noted above, Christianity was originally a Jewish movement; therefore, it is important to stress, that just as Abraham was paramount in Judaism, this patriarch became extremely significant in Christianity as 
well. ${ }^{15}$ Since the New Testament had a Jewish heritage, it is not surprising that this patriarch is used then. "The reason for Abraham's importance is that a variety of issues central to both early Judaism and Christianity converged around the figure of Abraham..." (Siker 15). Some of these issue include God's covenant promises, what it means to be heirs of these promises, the eschatological realization of the promises, law, circumcision, God's relation to non-Jews, and the meaning of both faith and righteousness. Most of these ideas will be described below. Essentially though, the inheritance of Abraham, and the development of him becoming a Christian figure, begins because he is a tool to prove the message and teaching of Jesus and his followers. In other words, Abraham, his life, and the Godly events that take place around him, become evidence for the message of the New Testament. Therefore, thid section will explain how Abraham is adopted in Christian ideology by going into key aspects of the Christian faith in which Abraham is an essential part of. Then there will be an explanation of the strategies that the early church used to begin to claim him. ${ }^{16}$

Before we delve into Abraham, it is important to note that the New Testament is not written by one author and by no means is it a monolithic discourse. Each letter or book was written for a reason and it was usually for a specific audience. For instance, the book of Luke was written by a Gentile for the Gentiles. This can be seen by the

\footnotetext{
${ }^{15}$ As noted in chapter 1, Abraham became an embodiment of God's promise to the Jewish people. God made a promise as well as a covenant in the book of Genesis; consequently, Jews in the $2^{\text {nd }}$ temple period believed that they inherited that partly because they were physical descendants of him.

${ }^{16}$ Before the investigator can understand the specific ways that the early Church claimed Abraham: use of Scripture, analogy, etc., it is important to first describe how he is used in the text. Abraham is used in numerous ways for differing reasons. For instance, as it will be shown later, Abraham is often referred to in matters of faith. According to the New Testament, it is the faith of Abraham in the promises of God that made him righteous; it was not law nor even his works. Abraham believed and it was counted to him as righteousness.
} 
substitution of Greek names for the many Hebrew names. On the other hand, Mathew, which was primarily written for a Jewish audience, uses more Hebrew. Also, the book of Matthew refers to Hebrew Scripture more often than Luke in the hope to prove that the Gospel of Jesus was already spoken about in the writings of early Judaism which adds to the evidence that the Gospel of Jesus was a fulfillment of Judaism or superseded it (Plummer xxxiii-xxxvi). Another significant aspect of the New Testament is that there have been a multitude of interpretations and viewpoints which have been drawn from this text. However, be that as it may, there seems to be an evolution of Christian thought in which Abraham becomes a major factor, and even though there are numerous interpretations and authors there can still be seen a clear view of Abraham concerning him being the proof for the Christian message. ${ }^{17}$

\section{The True Descendants of Abraham}

There are numerous discourses that revolve around Abraham; however, two of the primary concerns are who the true heirs of Abraham as well as the significance of that claim. Throughout the Gospels and the epistles, this idea is discussed in numerous ways. In some instances, there are varying view points on the importance of heritage. Therefore, an analysis of these significant uses are in order.

It is important to begin by looking at the book of John because it stands closer to the heat of the Jewish/Christian controversy more than any of the other texts in the New Testament (Siker 128). The purpose of this writing was to encourage the audience about their view of God, it was to give them a sense of 'legitimation' (Whitacre 17). According

\footnotetext{
${ }^{17}$ When Abraham is described during the rest of this work, the type of audience that the text is written for will be clarified. This clarification may not always be used because many of the same ideas concerning Abraham are used across audience; however, some aspects of Abraham may be highlighted for specific audiences.
} 
to Rodney Whitacre, this period was the beginning of a forced separation of Jewish Christians from the synagogue and was written in the context of persecution by Jewish oppressors (Whitacre 10). Therefore, there is a polemic toward the Jews that is harsh in comparison to the rest of the New Testament, especially in regards to the claiming of being a descendent of Abraham.

As noted earlier, being a descendent of Abraham is very significant in Judaism. It is important in contemporary times as well as times of antiquity. The Gospel of John goes a step beyond Luke and Matthew concerning the importance of this claim. As it will be seen below, Matthew and Luke hold varying importance in the matter; however, each argue that the claim to being a son of Abraham is not sufficient. John on the other hand, criticizes the Jewish claim in its entirety through the mouthpiece of Jesus. The chapter of notoriety is John 8; here Jesus claims that the Jews may be descendants of Abraham, but they are not children of him because they do not follow his example. In fact, Jesus states that their father is the Devil (John 8:44). It is important to note the context of this passage. Prior to this statement, the Jewish leaders are found plotting the death of Jesus (Dodd 453). In verses 39 and 40 Jesus states: “If you were Abraham's children, you would be doing the works Abraham did, but now you seek to kill me, a man who has told you the truth that I heard from God. This is not what Abraham did. You are not doing the works your father did..." Jesus knows that they are plotting to kill him; therefore, in verse 44 Jesus claims that their father is actually the Devil because they are really imitating him. Thus their identity does not stem from Abraham but from the devil (Schnackenburg 211). The rationale that Jesus is using is that they may be actual physical descendants of Abraham, but that does not mean they are his children. The child tries to 
emulate what his father does. In verse 24 Jesus states to the Jews, "I told you that you would die in your sins, for unless you believe that I am he you will die in your sins." In this statement Jesus is telling them that they are moving towards death, they are in the process of delivering themselves up completely and finally to the realm of death (Schnackenburg 199).

The point of this chapter in John is to show that the mere claim of being a descendent of Abraham is by no means sufficient. In actuality, it is virtually meaningless. The factor that really makes one a child of anything, is if they follow the footsteps of their father. Hence, if these Jews that Jesus was speaking to were truly children of Abraham, then they would be following Abraham, and this means that they would then believe the message that Jesus was proclaiming. Therefore, according to John, it is about the actions and beliefs of the individual that makes him a child of anything. Just simply claiming it is pointless in the eyes of John.

As stated earlier, the book of Matthew and Luke seem to be written for two different audience; one was primarily for Jewish understanding of Jesus, and the other was for a Gentile audience. Therefore, these two authors take a slightly different approach with each other and also with John. In the first verse found in the book of Matthew, the author states: "The Book of the genealogy of Jesus Christ, the son of David, the son of Abraham." Unlike the other gospel writers, the author of Matthew links Jesus to the lineage of Abraham from the commencement of his discourse. The reason that the author does this is to remind the audience that Jesus is Jewish (Keener). ${ }^{18}$ However, be

\footnotetext{
${ }^{18}$ It is important to stress that the first verse of Matthew was not only to show the evidence of Jesus' Jewishness. It is also likely that linking Jesus to David was an attempt to show that he was the Messiah and fulfilled the messianic hopes (Siker 79).
} 
that as it may, there is a suggestion of Gentile inclusion in the genealogy as well. In the midst of the tree of descendants, there are numerous foreign women Tamar, 1:3; Rahab and Ruth, 1:5; and the wife of Uriah the Hittite. Thus, according to Matthew, Jesus did not just fulfill the messianic hopes of the Jews, but he also intended to be the savior of the Gentiles (Brown 68). However, according to Jeffery S. Siker, Matthew never attempts to signal an extensive Gentile mission within his work; therefore, "he once again simply locates Jesus within the Jewish traditions, ties Jesus to the pregnant promises associated with Abraham, and as yet only hints at Gentile Inclusion" (Siker 80). ${ }^{19}$

The significance of being a descendant of Abraham in Matthew however is not yet concluded. In Matthew 3, John the Baptist is speaking to a crowd about following the ways of God. He is calling people to repentance because "...the kingdom of heaven is at hand" $(3: 2)$. However, there were a group of religious leaders in the crowd and when John the Baptist sees them he states:

"You brood of vipers! Who warned you to flee the wrath to come? Bear fruit in keeping with repentance and do not say to yourselves, 'We have Abraham as our father,' for I tell you God is able from these stones to raise up children for Abraham."(Matt 3:7-9) ${ }^{20}$

It is important to note, that this verse highlights a common theme found in many of the Gospels concerning the religious leaders in Jesus' day. There are over ninety nine references to them and thirty of these are found in Matthew (Siker 220). There is a

\footnotetext{
${ }^{19}$ Concerning being a decedent of Abraham, the Gentiles are a major factor. So far, it has only been hinted that some works suggest gentile inclusion. This mostly concerns the Gospels; however, concerning the book of Acts and the epistles of Paul, Gentile inclusion is a major factor. Gentiles were considered children of Abraham; however, this will be explained in the next section because it concerns a reinterpretation of the promises of Abraham and it is necessary to attempt to separate the reinterpretation of the promises.

${ }^{20}$ This passage finds an important parallel in Luke 7.
} 
common animosity between the writers and the Jewish leadership; however, the significance of this verse seems to emphasize an over confidence that Jewish leaders had. However, the polemic found in Matthew is not as harsh as the polemic found in John. Be that as it may, the warning in Matthew 3:9 indicates that mere reliance upon Jewish heritage does not suffice for salvation. In order to lay legitimate claim to Abraham as a father, one must "bear fruit that brings repentance" (3:8). In other words, true descendants of Abraham are not Jews who necessarily come from the blood line of the patriarch. Here, like in John as well as in Luke, this verse suggests that actions are required.

Thus, there is a question that begins to be raised, who are the descendants of Abraham? In Matthew 8 there is a theme that begins to rise. In this specific story, there is a Gentile centurion whose servant is very sick. The centurion sends for Jesus to come and heal his servant; however, when Jesus gets close, the centurion protests and tells him that if Jesus simply states the healing, it will be done. The centurion did not feel worthy enough to be in Jesus' presence. Jesus heals the servant with his words and then makes a proclamation

"Truly, I tell you, with no one in Israel have I found such faith. I tell you, many will come from the east and west and recline at the table with Abraham, Isaac, and Jacob in the kingdom of heaven, while the sons of the kingdom will be thrown into outer darkness. In that place there will be weeping and gnashing of teeth" (Matt 8:10-12)

The statement above finds its parallel in Luke 7:1-10 and it is filled with meaning that needs to be discussed. The first important aspect is the hint of Gentile inclusion to the kingdom of God: "...many will come from the east and the west." If this proclamation is true, then what about the Jewish people? The latter part of 8:10-12 is an explicit 
exclusion statement. "The Jews who do not demonstrate faith (like this Gentile) will be cut off from the kingdom, while the Gentiles who do exhibit faith will find themselves included in the kingdom and will sit at the table with Abraham" (Siker 84). It is not the heritage but the intense faith and devotion that one has which makes him a son of Abraham. ${ }^{21}$

Not unlike Matthew, the Gospel of Luke also has a very similar discourse. According to this author, it is faith that is the defining factor of claiming sonship to Abraham. As stated above, Luke also has John the Baptist calling the Jewish leadership a brood of vipers and demeaning the sufficiency of the claim to the heritage of Abraham (Luke 3:7-9). However, unlike Matthew, during Luke's description of Jesus' genealogy, he begins with Joseph and ends with Adam. Consequently, Abraham seems to have no specific importance in the genealogy, in Luke 3:34, Abraham appears as one of the seventy-seven names and gets buried in the list (Siker 109). Therefore, the parallel between Luke with Matthew revolves around the element of faith that an individual has. For instance in Luke 5, Jesus heals a paraplegic because of the faith of him and his friends. In this instance, Jesus is speaking at someone's house and a group of people cut a hole in the roof and lowered the paralyzed man by the rope. Because of their faith, Jesus healed them (Luke 5:19).

It is important to note something unique in the Gospel of Luke concerning the identity of the sons of Abraham. Faith is one aspect that surrounds the definition of who the sons of Abraham are; however, there is another factor that is utilized as well in Luke,

\footnotetext{
${ }^{21}$ The faith component to the Abrahamic discussion will be discussed in more detail during the analysis of Paul.
} 
the individual's social status and piety. This is especially emphasized in the first chapter of Luke where Mary and Zechariah both pray to God. These prayers are very unique in the New Testament and according to Raymond Brown, the origins are best found within the communities of Jewish Anawim who had been converted to Christianity (Brown 350). The term "Anawim" initially referred to those who were physically poor but came to refer more broadly to those on the fringe of society. These individuals were destitute because of sickness, being widowed, orphaned or socially outcast (Siker 104). The Anawim looked to the power of God for deliverance. There was a special piety in these individuals and Luke was sympathetic to them, and throughout the book of Luke as well as Acts, Abraham is often in close proximity with these individuals. One remarkable healing that is recorded in Luke, which is found in chapter 13, has Jesus healing a crippled woman who is worshiping in the Temple on the Sabbath. What makes this story stand out is that Jesus initiates the healing; she doesn't ask for it. Jesus also calls her a "daughter of Abraham". She is clearly an Israelite because she worships in the temple; however, it has been argued earlier that Luke did not find great significance in being an actual physical descendent. ${ }^{22}$ The setting points to the answer. Although she was suffering from an intense sickness, she still found herself worshiping in the Temple on the Sabbath. "By calling her a daughter of Abraham, Luke has Jesus identify the woman as a long-suffering pious individual who becomes the object of God's special mercy" (Siker 111). Therefore, it is the woman's intense devotion in the midst of pain and sickness that makes her a 'daughter of Abraham'.

\footnotetext{
${ }^{22}$ In Luke 3, through John the Baptist, the author shows that being a physical descendent does not suffice for salvation.
} 
Piety is also highlighted in the story of Zacchaeus' which is found in Luke 19. Zacchaeus was a tax collector and had an intense desire to see Jesus. In one moment in particular, there was a crowd that surrounded Jesus, so Zacchaeus decided to climb a tree in order to see him. Jesus took note of the initiative and told him that he needed to stay in his house. Zacchaeus accepted him joyfully and told Jesus that he would give half of his belongings to the poor and if he defrauded anyone anything, he would restore it fourfold. This is a story of repentance, and because of Zacchaeus' actions, Jesus called him a 'son of Abraham' (Luke 19:3). Therefore, this alludes back to John the Baptist's statement about what constitutes being a true heir to Abraham. Essentially, one can't claim special significance through heritage to Abraham, it has to come about through repentance (Plummer 435).

The book of Acts also reveals these same qualities to be considered in regards to what makes an individual a child of Abraham: repentance, faith, and piety. However, before continuing, it is important to note the purpose of Acts. Acts is an account of the early deeds of the Church. This book is extremely important because it shows a transition from an explicitly Jewish outreach in the first half to a Gentile mission in the second half. Hence the author, who is commonly believed to be the writer of Luke, makes a transition to the explicit inclusion of the Gentiles within God's promises to Abraham. ${ }^{23}$

The first major event in Acts is the Apostle Peter's speech at the temple. ${ }^{24}$ This is found in Acts 3:11-26. His speech follows a healing of a lame beggar (3:1-10) which

\footnotetext{
${ }^{23}$ Described below.

${ }^{24}$ I will be returning to this speech later in addition to Stephen and Paul because they have another aspect that is important, a reinterpretation of the promises to Abraham. I will explain this reinterpretation in the next section where I will analyze how the author of Acts and other writings of the New Testament
} 
follows the same pattern of healings that is found in Luke The lame beggar did not ask for a healing or even expect one; also he neither repented nor exhibited faith in Jesus before the healing took place. Instead, Peter initiated it himself just as Jesus initiated the one with the crippled woman; likewise, just as Jesus called the crippled women 'the daughter of Abraham' so here Peter attributes this healing to "the God of Abraham, Isaac and Jacob" (Acts 3:13). Therefore, in this section and throughout the book of Acts, God extends mercy in a special way to those who are poor and outcast (Siker 118).

The purpose of Peter's speech is twofold. The first reason is to explain the occurrences going on around them and the second is to call the people to repentance. Prior to the healing of the lame beggar, the apostles received the Holy Spirit in a very miraculous way. Acts 2 records rushing winds and loud noises; consequently, there was a crowd that gathered around the place to discover what was happening. They saw the apostles and when the apostles spoke, the people who gathered around would hear them speaking each in their native language (Acts 2:5). Consequently, some of them stated that they were just very drunk. Hence, Peter wanted to clarify that what was happening was not because of alcohol, but because God was moving among them (Acts 2:14-16).

The second reason Peter is speaking is to tell them about Jesus. Essentially, Peter was arguing that Jesus was the prophesied messiah who was raised from the dead; however, what is significant is Peter accuses the multitude which was gathered of being responsible for crucifying this messiah. ${ }^{25}$ Therefore he called everyone to "repent and be

(especially Paul), reinterpret aspects of the promises found in Genesis 15 and 17. However, the speech of Peter, Stephen, and Paul show other important things as well. In each speech, there are reinterpretations of the promises made to Abraham; however, there is also a call to repentance which is open for both Jew and Gentile. 
baptized every one of you in the name of Jesus Christ for the forgiveness of your sins...for the promise is for you and for your children and for all who are far off, everyone whom the Lord our God calls to himself" (Acts 2:38-39). Through Peter, the author of Acts, suggests action needs to happen. According to Barnes, the author of Acts was calling men to genuinely turn from his sin. "Religion demands that he should at once surrender himself to God...by confession that God is right and that he is wrong; and by a firm purpose to live a life of holiness" (Barnes). In the same way that Zacheaus turned away from his sin, this multitude needs to do the same thing. Then they can start over and "save themselves from this crooked generation" (Acts 2:41). ${ }^{26}$

\section{Reinterpretation of the Promises of Abraham}

Deciphering who is a descendent of Abraham was very important in early Christianity. During this time of the early church, the book of Acts reveals that there was a massive influx of believers; however, many of these were from non-Jewish origins. Therefore, there was a need to connect these individuals to Abraham in some way. It was briefly noted above, that there are hints in the Gospels of Gentile inclusion into the Abrahamic family; consequently, it became important to re-examine certain texts from Hebrew Scriptures in order to legitimize this change. The majority of this analysis that the early church performed revolved heavily around Abraham and his promises found in Genesis 15 . The current section will focus on how the early church reinterpreted the promises to not only show how the Gentiles are also considered the children of Abraham,

\footnotetext{
${ }^{25}$ This is found in Acts 2:23 and 2:36

${ }^{26}$ The original statement was "save yourselves". I replaced the word in the hope of a better understanding concerning the context.
} 
but that there has been a misinterpretation of numerous ideas that are central to Jewish thought concerning what brings righteousness, what is faith, and what the fulfillment of the promises actually are.

The individual who arguably did the most concerning Gentile inclusion was Paul. ${ }^{27} \mathrm{He}$ is believed to have written 13 letters of the New Testament and his missions in Acts was mostly bringing the message of Jesus to the Gentiles. He also wrote a lot about Gentile inclusion concerning the Abrahamic family; however, he only wrote about Abraham in areas where there was controversy between Jewish-Christians and Gentile Christians. Where this conflict did not exist, he more or less does not appeal to Abraham as evidence for his teachings (Siker 28). Therefore, the works that concern Abraham are found for the most part within Galatians and Romans.

It is important to begin, in regards to Paul, with his view of what makes an individual a descendent of Abraham. As it has been noted before, that throughout the New Testament, there was an ongoing debate about the requirements of the believer in Christ. Part of the debate during the council in Jerusalem (Acts 15) is whether or not the Gentiles had to follow the Law of Moses. The idea is very significant for Paul in his letters. In Galatians 2 he emphasizes that what truly matters in regards to being a true descendent of Abraham is not the works of the law but faith. In verses 2:15-16 Paul writes "...we know that a person is not justified by works of the law but through faith in Jesus Christ, so we also have believed in Christ Jesus, in order to be justified by faith in Christ." Paul here is speaking on behalf of himself; consequently, as a Jewish Christian,

\footnotetext{
${ }^{27}$ The apostle Paul focused a lot of his discourses in some of his epistles to reinterpreting Genesis and the idea that there were misconceptions that the Jews were following.
} 
Paul is claiming that even the Jewish-Christians know this fact (Hansen). Thus, the purpose of his letter addressed to the Galatians was to respond to the Jewish-Christians who were teaching the Gentiles the necessity of circumcision and law observance. The element that makes one a believer is receiving the Spirit by faith (Galatians 3:2); therefore, following the Law has little importance.

Paul essentially distances Abraham from the Law within his letters of Galatians and Romans. In Galatians 3, he refers to Genesis 15:6 which states "And he believed the LORD, and he counted to him as righteousness." This is how Paul proves his point of view; Abraham was deemed righteous not because of anything he specifically did, but because of his belief (Siker 36). In fact, according to his later letter, in Romans 4, Paul's circumcision followed the proclamation of the Divine concerning Abraham's righteousness; it did not precede it. "Paul here applies a common Jewish interpretive toolContext... and some Jewish interpreters have the circumcision following 13-29 years after this proclamation" (Keener).

Paul's declaration of an individual's faith being the prime factor of his claim to Abraham sets the argument up to answer a new question, who then are the children of Abraham? He precedes to reinterpret a mixture between Genesis 12:3 and Genesis 18:18 in Galatians 3:8 which reads "And the Scripture, foreseeing that God would justify the Gentiles by faith, preaches the gospel beforehand to Abraham, saying 'In you shall all the nations blessed." 28 According to Paul, God's promise to Abraham refers to the inclusion of the Gentiles (Barrett 34). "In other words, God's purpose all along was to reach the

\footnotetext{
${ }^{28}$ Genesis 12:3 states: "I will bless those who bless you, and him who dishonors you I will curse, and in you all the families of the earth shall be blessed." Genesis 18:18 states: "seeing that Abraham shall surely become a great and mighty nation, and all the nations of the earth shall be blessed in him?" The "in you" comes from Gen. 12:3 while "all the nations" comes from Gen. 18:18 (Siker 210).
} 
Gentiles too...In Jewish thinking, the righteous (Israel) were saved (blessed) in Abraham; here though, believing Gentiles are saved (blessed) in him" (Keener). Paul states this again in a different way during the $4^{\text {th }}$ chapter of Romans, "as it is written, 'I have made you the father of many nations'-in the presence of the God in whom he believed against hope, that he should become the father of many nations, as he had been told, 'so shall you offspring be'"(4:18). Here Paul is quoting Genesis 17:5 and is again implying that the Gentiles are these "many nations" (Moxnes 233).

In Romans 4:18, Paul also begins to draw a parallel to reveal that Gentiles and Jews were both heirs to Abraham. He does this explicitly by comparing the faith of Abraham to Christian faith. In short, there are three similarities between the two: the theocentric focus of belief, the emphasis on God's power to make the dead alive, and the trusting attitude of the believer, who in hope believes against hope. The second aspect deserves elaboration; Christians believed in the resurrection of Jesus; however, Abraham did not. Be that as it may, Paul states that Abraham believed that God would enliven his own son from the dead (Siker 63). This was why Abraham had such faith in God that he would sacrifice his only son. He hoped, against all hope that God would raise him from the dead and fulfill his promise. In the eyes of Paul, the structure of Abraham's faith in Genesis is the same as Christians. Paul's idea is more evidence for his argument that Abrahamic faith and Christian faith are similar.

The reinterpretation of Scripture was not only used to reveal that God intended Gentiles to be the heirs of Abraham but also that there is a misconception about the land that Abraham was to inherit. Paul, as well as Acts, reinterprets the Abrahamic promise itself. In Judaism, the Abrahamic promise was about being the people of God, but it was 
also about a receiving of land. It was a promise that the children of Abraham would have a home to dwell and call their own. However, according to Paul and the writer of Acts, the land was not part of the original promise. For Paul it was about the receiving of the Spirit of God and not land (Galatians 3:26-4:7). The promise was about the eventual receiving of God's Son Jesus; consequently, according to Paul, through Jesus mankind becomes sons of God (Gal 4:4). They are adopted as sons through Jesus and this was the ultimate fulfillment of the promise to Abraham. Essentially, Paul uses Abraham and reinterprets the Promise completely. He makes it compatible with the Christian message.

The author of Acts also reinterprets the promise made to Abraham. As noted before, Acts 3 is Peter's address to the people. Within this speech, the author has Peter saying something very similar to Paul. He reinterprets Genesis 22:18 which states, "In your seed shall all the families of the earth be blessed." ${ }^{29}$ However, what is different from the argument of Paul is that according to the author of Acts, the Jews received the promise first, but since not 'all the families of the earth were blessed' Jesus was sent to fulfill the last part of that promise (Acts 3:26). It is important to note another highly contested debate in scholarship concerning 'your seed'. Is this word referring to a collective or singular? Does seed refer to Israel, or as often interpreted, as Christ (Haenchen 209)? If it refers to Christ, then salvation to the Gentiles is not mediated through God's blessing on Israel but comes only through Jesus, independently of Israel. This means that the promise was never connected to Israel since the time of Abraham; it was only connected to Jesus. According to Siker, the author of Acts affirms both because

\footnotetext{
${ }^{29}$ There is a general agreement among scholars that the author's purpose is to point clearly to the inclusion of the Gentiles in the promise of Abraham (Bruce 220).
} 
"The verses preceding the reference to 'the seed of Abraham's focus on Christ, whom God has appointed for Israel (3:20). Second, the author makes it clear that God has sent Christ to bless Israel (3:26), perhaps the author saw here, that Israel was among the recipients of God's covenant promise to Abraham as well (3:25)" (Siker 119-120).

Another way that the author reinterprets the promise of Abraham is through the speech of Stephen. Stephen was one of the early followers of the Church. His speech takes place during his trial where he was accused of "speaking against God and Moses, against the Temple and the Law; he has said that Jesus would destroy the Temple and the Customs handed down to the Jews at that time" (Kilgallen 6). These were very serious charges, and his speech was a legal defense. He roughly re-narrates the history of Israel and part of that narrative regards Abraham. There is an aspect of Stephen's speech that is not unlike Paul; it regards the promise that God gave to Abraham. However, for Stephen, he does not focus on Jesus as the promise, but the inheritance of the land. In Acts 7:7 Stephen states "But I will judge the nation which they serve, said God, and after that they shall come out and worship me in this place." Steven quotes Genesis 15:14, however he changes the ending. ${ }^{30}$ Acts 7:7 has the beginning of Genesis 15:14 but it adds the ending of Exodus 3:12 (Kilgallen 35). ${ }^{31}$ This is one of the main reasons the ending of Acts 7:7 is highly contested. The camp of Killigan believes that it represents the temple; however, Sikler believes it was a general reference to the land (Siker 123). Regardless of the view, Stephen makes a point that the purpose of God giving the land in the first place was true

\footnotetext{
${ }^{30}$ Genesis 15:14 states; But I will bring judgment on the nation which they serve, and afterward they shall come out with great possessions.

${ }^{31}$ Exodus 3:12 states; "When you have brought forth the people out of Egypt, you shall serve God upon this mountain."
} 
worship (Brawley 120). In verses 6-7 Stephen points out that Abraham wandered the land; he never actually received any physical inheritance. Instead, throughout his journey, from Mesopotamia to the Land of Canaan, Abraham worshiped God everywhere (Bruce 135). True worship, according to Stephen, thus transcends the idea of a promised land. The focus becomes Christ.

\section{Conclusion}

It is clear, that in review of this study, Abraham is of prime importance to the early Church. The main strategy that Christianity used in order to prove their points is a reinterpretation of scripture. The scripture that was used, was the narrative of Abraham itself. Essentially, the interpretations of the writers superseded not only Jewish scripture, but also the interpretation of the scripture itself. Through that story and a reexamination of the promises, through the use of Abraham, the writers of the New Testament were able to prove their world views. For instance, the early Christians showed that it is faith, and not works, that truly make one not only a descendent of Abraham, but essentially a child of God. Also through Abraham, the New Testament authors were able to show the importance of the Gentile. The Gentiles are no longer random outcasts that need to conform to Jewish law; on the contrary, the doctrines that came from the New Testament authors superseded this idea. The gentiles only need to emulate Abraham especially in the way of his faith. Another way that the New Testament writers were able to prove their views was by parallelism. Luke especially shows this idea. Luke draws a parallel with the outcasts of society to Abraham. He shows that the father of the Jewish people was an outcast and marginalized and God has a special place for those who are on the peripheral of society. Also, it is through their faith and piety that they become children of Abraham 
and essentially heirs to the promise. Even the promise itself was re-analyzed, and through that was the discovery that the Jews were mistaken about the meaning. The promise was not essentially about having a land to call their own; on the contrary, it was partly about receiving a place to worship. Even that was not the complete promise; the fulfillment of the words that are found in Genesis 15 and 17 are found in the death and resurrection of Jesus.

The idea of Christianity superseding the views of Judaism echoes strongly within the New Testament. As noted above, there are numerous ideas that come to replace old ways of thinking: who is a descendent, the promise, faith and righteousness, etc. All these conceptions are portrayed through referencing Abraham. It is interesting that Christianity doesn't only seem to supersede, but in a way it is a call back to the original Abrahamic religion. As noted in the writings of Paul, Abraham did not practice the law. The law was a guardian to the promise; hence, receiving Jesus and holding fast to him in faith, resembles the same aspects that Abraham had with his faith. He held firm to the promises of God in the same way that Christians hold fast to Jesus. He hoped against all hope that what God promised him would come to pass; likewise, the early Church saw themselves doing the same action. It is clear, that in the early Church's eyes, the Jesus movement was a reorientation on the correct path to God. Somewhere along the way, according to the Christians, the Jews missed the mark, and Jesus paved the way back to repentance. 


\section{THE ISLAMIC ABRAHAM}

\section{Introduction}

The Prophet Abraham is an important part of the Islamic belief system. However, before delving into Abraham within Islam it is important to emphasize some common misconceptions. The Qur'an, is the sacred scripture of the Islamic faith and it is the divine revelation given to the Prophet Muhammad. It is important to stress, that the Qur'an is not about the life, deeds, or actions of Muhammad. The revelation of Muhammad speaks about the prophets prior to him; these include the patriarchs as well as the prophets of Jewish scripture and the Christian New Testament: Abraham, Moses, Jacob, Ishmael, Isaiah, Jesus, etc. In other words, it can be argued that the Qur'an can be seen as a continuation of the messages of these individuals. It is important to stress though that many Muslims do not see the Qur'an as a continuation of Jewish and New Testament scripture. In many cases, the revelation was directly from the Divine and it did not follow any other divine message. ${ }^{32}$ Essentially, "the monotheism they (the prophets/patriarchs) preached was the same as that preached by the Arab Prophet (Muhammad) and their stories are simply the descriptions of the vicissitudes that were subject to their respective peoples" (Tottoli ix). The Qur'an is not a new revelation; it stresses more of a theme about remembrance, remembrance of the message that God originally gave to his prophets. Sura 4:163 states; We have sent revelation to you [Prophet] as We did to Noah and the prophets after him, to Abraham, Ishmael, Isaac,

\footnotetext{
${ }^{32}$ Below it is discussed briefly how the revelations given to Abraham, Moses, Jacob, Jesus, etc. were corrupted. The revelation given to Muhammad was virtually the same as that given to Abraham.
} 
Jacob, and the Tribes, to Jesus, Job, Jonah, Aaron, and Solomon - to David We gave the book [of Psalms] -."33

It is also important to note what a prophet is in regards to Islam. Though it is beyond the scope of this present chapter to investigate all the aspects of what it means to be a prophet, the characteristic that is important is each prophet is given a revelation from God. As noted earlier, this revelation is the same; however, the mouthpieces are different. The prophet is an individual tasked with not only sharing the revelation from God but to lead his group or people on the right path that God has originally intended for humanity. "The Prophets came in order to convey to human beings Divine knowledge, free of all forms of illusion and error" (Musavi Lari 11). This knowledge and lifestyle can't be deduced by logic and reason; it is only revealed by God.

Thus, Abraham becomes important in regards to the purity of the faith. He is a rallying symbol in both Mecca and Medina for one major reason which is to show that the early community of believers did not borrow certain ritual practices from neither polytheists, Jews, nor Christians. ${ }^{34}$ The use of Abraham in Islam mostly revolves around the Qur'an's polemic discourse with both Christianity and Judaism. As noted before, the patriarchs and prophets of the Bible are also considered prophets within the Qur'an. Muhammad was seen as the heir of the Biblical tradition that both the Jews and the Christians claimed to follow (Tottoli 9). There is no doubt that the Qur'an and the early Muslims believed that the Jewish people were blessed and chosen by God; "Children of Israel, remember how I blessed you. Honor your pledge to Me and I will honor My

\footnotetext{
${ }^{33}$ All citations from the Quran will come from M. A. S. Abdel Haleem's translation of the Quran which was published by Oxford University Press.

${ }^{34}$ This is expanded on below in regards to the occasion of revelation.
} 
pledge to you: I am the One you should fear" (Q 2:40). ${ }^{35}$ Though the people were chosen, they violated and broke their pact with God; "And so for breaking their pledge, for rejecting God's revelations, for unjustly killing their prophets, for saying 'Our minds are closed' - No! God has sealed them in their disbelief, so they believe only a little-" (Q 4:155). ${ }^{36}$ The next few verses of the Qur'an accuse the Children of Israel of debarring others from God's path, taking usury, and stealing property (Q 4:160).

As noted above, Muhammad was seen as the heir of the biblical tradition; however, the reason that there was a need for Muhammad is that the message of the Jews and Christians became corrupted; "it was under these circumstances that the promised deliverer Muhammad was born" (Musavi Lari 80). The notion of corruption became commonly referred to as tahriff. It is the change, alteration, and forgery of the words of Scripture that Jews and Christians have perpetrated according to the Islamic perspective (Lazarus-Yafeh). Within the Qur'an itself, there are numerous verses that suggest a distortion of the original meaning of the revelation that was given to Christians and Jews. “...But they broke their pledge... They distort the meaning of [revealed] words and have forgotten some of what they were told to remember: you prophet will always find treachery in all but a few of them. Overlook this and pardon them...” (Q 5:13). Though this verse seems lenient due to its command to overlook and pardon them, there are other verses that have a more severe context. Q 2:75 states, "So can [believers] hope that such

\footnotetext{
${ }^{35}$ For the rest of this project Q stands for a Qur'an reference.

${ }^{36}$ It is important to note that the Qur'an is not written chronologically. Consequently, many ideas are spread throughout the Qur'an as a whole. In this way, the Qur'an differs from both the Hebrew Scriptures as well as the Christian New Testament.
} 
people will believe you, when some of them used to hear the words of God and then deliberately twist them, even when they understood them?"

These above verses reveal a debate that is found in both early Islam as well as contemporary Islamic thought which is the process, intention, and purpose of the corruption of God's revelation which was given to Jews and Christians (Lazarus-Yafeh). Some scholars suggested that it was accidental and changed overtime. While the oral recitation of scripture was used, there were slow and gradual changes to what was said. Others, like Ibn Hazm (994-1064) believed that the Jews and Christians intentionally falsified God's revelation for their own gain (Lazarus-Yafeh). The latter view was the one most commonly believed in Muslim thought. Be that as it may, Ibn Hazm was one of the great apologists for this idea and he believed that the corruptions are found in six categories: "Blasphemy, geographical and historical impossibilities, contradictions (particularly in the chronology of the patriarchs), cases of obscenity in which even the prophets' and the families are involved, adultery, and lies and deception" (Rif'at 221).

The major function of tahrif $f$ was to explain the inconsistencies found between the Christian and Jewish revelations and their Islamic counterpart (Lazarus-Yafeh). This can be seen in regards to the story of Lot. In Judaism, as well as Christianity, Lot was not a prophet; he was just a nephew of Abraham. Part of the narrative of this individual in the Christian and Jewish narrative is that there is a moment where Lot gets exceedingly drunk and impregnates his two daughters (Genesis 19). Islam completely rejects this notion because in its theology, Lot is a prophet who follows and believes in the message of Abraham. He decides to share this message to a group of his followers that were 
profoundly wicked (Tottoli 28). Thus, the story of his incest does not occur in neither the Qur'an nor any other Islamic narrative; therefore, it was a fabrication (Rif'at 230).

In light of this context, Abraham was used in a very interesting way. He seems to be used with almost an apologetic intention. Just mentioning Abraham brings a remembrance of what the religion of God should have been prior to Judaism and Christianity.

Thus, the message of Muhammad does supersede the teachings of both Christianity and Judaism due to the corruption that they hold; however, it is not so much as superseding as a turning back to the original revelation of Muhammad. The Qur'an appeals to Abraham and claims that its message is identical to the revelation of Muhammad. Abraham was not a Jew nor a Christian; the religion that he followed resembled more of what Muhammad claimed. Essentially, Abraham becomes an embodiment of what Islam represents.

\section{The Narratives of Abraham}

The narrative of Abraham found within Islam is important to investigate because, like Judaism and even Christianity, Abraham becomes an embodiment for the teachings of Islam and the Qur'an. ${ }^{37}$ It is important to note here that, unlike the Hebrew Bible, the narrative of Abraham, as well as other Biblical prophets, is fragmentary. "It assumes in homiletical fashion that the listener is already familiar with the broad topics being discussed" (Firestone 9). The reason for this is that even in pre-Islamic times, many of the Biblical legends like David, Daniel, Solomon, etc., were well known. It is important to emphasize that the majority of people were illiterate; consequently, religious stories

\footnotetext{
${ }^{37}$ This will be discussed in the next section.
} 
were essentially passed down orally (Firestone xi). Muhammad and his early community were in contact with both Jews as well as Christians. There was trade as well as a sharing of stories. Therefore, while the Qur'an was being put together, there was an assumption that people already knew the majority of the stories. This section will investigate the Abrahamic narrative found in the Qur'an as well as in the oral tradition of the Arab people. $^{38}$

It is important to note before delving into the references of Abraham a significant observation in regards to the Qur'an, the context of revelation. The Qur'an was revealed over a span of 20 years during different events in the Prophet Muhammad's life. Also, the Qur'an is not revealed, for the most part, in chronological order. In scholarship, the revelation is generally broken down into two specific periods in Muhammad's life: the time he lived in Mecca and the time he lived in Medina. ${ }^{39}$ These two time periods still tie in together in a significant way. While in Mecca, Muhammad was surrounded by a multitude of differing religious outlooks. There were polytheists as well as Jews and Christians. This community prided itself in the sacred stone that would become known in Islam as the Ka'ba. Muslims adopted this sacred stone; therefore, the appeal to Abraham

\footnotetext{
${ }^{38}$ Further on in this chapter, the oral tradition finds prominence due to the fact that there seems to be a sharing of common ideas primarily between the Jewish narrative of Abraham and the Islamic counterpart.

${ }^{39}$ There are 8 specific suras that are referred to throughout this project $(2,3,6,11,21,22,26$, and 37$)$. It is important to note, that there are different lists both ancient and modern about the period of time each verse was revealed. According to Muhammad Assad's work, The Message of the Qur'an, the majority of these suras belong to the period of the Prophet's residence in Mecca ( 6, 11,21, 26, and 37) and the other three belong to the time he resided in Medina $(2,3,22)$ (Asad). However, he is describing one of the lists which is the Egyptian Standard Chronological Order.

According to Gerhard Böwering, both Muslim and Western scholars have struggled with this issue as well. Not all of the suras are highly disputed though, for the most part, Qur'anic scholars agree at least with the time frame of most of the revelations; however, the suras which are highly contesdt, especially in Muslim circles are Q $13 ; 47 ; 55 ; 57 ; 61 ; 64 ; 83 ; 95 ; 97 ; 98 ; 99 ; 100 ; 102 ; 107 ; 112 ; 113 ; 114$, which total 17 (Böwering).
} 
in Mecca is extremely significant because it shows that Muslims did not borrow from the polytheists nor the Christians and Jews for that matter. Abraham preceded these individuals and claiming him in Mecca was a statement that Islam was the original religion of Abraham and the other religions worship a distorted version of it (Rippin 21). Also, the revelation in regards to Mecca were generally attempts to point out the corruption in society. Likewise, the revelation that came to Muhammad during his stay at Medina is very similar. The Jewish tribes refused to accept Muhammad as a prophet and even took up arms against him and his followers (Lassner 156). Muhammad and his people destroyed these tribes. Also it is important to highlight that few Jews were actual converts during the period of Muhammad's life. While he lived, it is estimated that little more than twenty Jews accepted Muhammad's revelation and prophet hood (Shtober 66). Therefore, the historical context of the references to Abraham are similar.

The story in the Qur'an regarding Abraham that has the most detail revolves around him destroying idols. The Qur'an dates this narrative early on in his life because he was a youth (Q 21:60). It is clear in the Qur'an that Abraham was a monotheist, but within four different suras the Qur'an pits Abraham against polytheists who were idol worshipers. In most cases, the father is the first object of reproach because he is one of the chief idolaters (Tottoli 23). ${ }^{40}$ Abraham urged his father to desist from worshiping these carved images and turn to the one true God. Abraham asks his father and the devotees with him “'do they hear you when you call? Do they help or harm you?' They replied 'No, but this is what we saw our fathers doing.'” (Q 26:72-73). Then Abraham

\footnotetext{
${ }^{40}$ This story is very significant in the oral tradition of Islam.
} 
begins to speak about the 'Lord of Worlds' who helps, guides, sustains, resurrects, forgives, and judges (Q 26:77-82). After Abraham critiqued the idea of idol worship, he is found alone in the midst of many statues. He essentially began to ask the idols themselves to prove their existence; "'Do you eat? Why do you not speak?" (Q 37:92). When there was no response, he defamed them by destroying them with his own hand. He was captured by the people and the punishment was to throw him into a blazing fire (Q 37:97). However, God had different plans and sent his angels to cool the fire which inhibited the burning of Abraham (Q 21:71).

The story of Abraham and the idols is peculiar because it does not come from the Biblical text. Though in Hebrew Scripture, Abraham's father was considered an idol worshiper (Joshua 24:2), there is not the notion him neither creating these statues, nor destroying them either. On the contrary, there is a lack of detail concerning this time of his upbringing. Be that as it may, the Qur'anic story of Abraham and the idols seems to derive from the Jewish oral traditions which have both of these details, specifically the Jewish Legends (Ginzberg 186-203). ${ }^{41}$ The Jewish story is very similar to the Islamic retelling of the story; however this will be described later. ${ }^{42}$ The narrative found within the verses of the Qur'an follow the same plot as the Jewish legend of Abraham: he speaks out against idol worship, breaks the idols, is arrested, thrown in a fire, and saved by God.

Another important narrative of Abraham is found in Q 11:69-76. Here, angels came to Abraham to bring good news to him about the birth of his son Isaac from his barren wife Sarah. Abraham tried to give them a meal but the angels did not attempt to

\footnotetext{
${ }^{41}$ Ginzberg derives his story from the Genesis Rabbah which is dated around $5^{\text {th }}$ century C. E. This predates the time of the Prophet Muhammad (Herr and Wald 449).

${ }^{42}$ The recitations of the stories of the prophets are used to add details to the stories.
} 
eat it or even reach for it. Thus, Abraham became afraid of judgment; however, the angels came to 'go against' the people of Lot (Q 11:70). When they pronounced the news that Sarah was to have a son, she laughed and was skeptical of their proclamation but the angels stated that it was ordained by God (Q 11:73). After this exchange that Abraham and Sarah had with the messengers, the fear in Abraham started to subside and he began to plead for the people of Lot that were about to be judged.

The story of Isaac's birth and Abraham's conversation with divine is important for numerous reasons; it shows that Abraham was tenderhearted and devout. However, there is another interesting element that can be shown by comparing it to its Jewish counterpart. Unlike the story of the idol breaking, this situation that Abraham found himself in is also told in Hebrew Scriptures, specifically Genesis 18:1-33. Here there is a mirroring between the Bible and the Qur'an in regards to a Divine visit (Lodahl 9). Though there are many details that don't match up, the overall outline is virtually identical: divine beings visited Abraham (Gen 18:1), Abraham attempted to be hospitable and fed them with a calf (Gen 18:5), Abraham's wife was promised a son (Gen 18:9-10), His wife laughed (18:9), she was skeptical (18:11), and Abraham pleaded with the divine beings concerning the fate of Sodom (18:22-25). ${ }^{43}$

\footnotetext{
${ }^{43}$ The purpose of this work is to show how both Christianity and Islam use similar means to claiming Abraham; therefore, it is beyond the scope of this project to delve into the differences concerning the details of this story. According to authors like Michael Lodahl, who is a Christian theologian, the differences surround the theological disagreements between the two faiths. One such difference is found between Genesis 18:26-33 and Q 11:76. In the Genesis passage, Abraham pleads with God to spare people in Sodom. He asks the Divine that if He finds any righteous people within the city will he continue with His plan to destroy it? God essentially says that if he even finds one he will spare the city. This dialogue is very different in the Quran; verse 11:76 states "O Abraham, desist from this; the Command of your Lord has come and an irreversible punishment shall smite them." According to Lodahl, the Qur'an "cleans up the image of God" (Lodahl 17). Within Judaism, as well as Christianity, there are numerous questions that arise like if Abraham changed the mind of God. This is a massive theological complexity that involves God's omnipotence. However, in regards to the Qur'an, the Islamic sacred text avoids this dilemma altogether.
} 
The Qur'an also mentions another important event in Abraham's life; the sacrifice of his son. This is found in Q 37:101-9. His son was running to him and Abraham told him that he saw a dream of him sacrificing his son. The son did not argue with his father; however, when it became apparent that Abraham, as well as his son, submitted to God and would do the deed without hesitation, messengers called out to him saying "'Abraham, you have fulfilled the dream.' This is how We reward those who do good--it was a test to prove [their true characters] -" (Q 37:104-6).

This passage also has a parallel in Judaism which is found in Genesis 22. As noted in chapter 1, Genesis 22 is known as the 'Binding of Isaac' or the Aqedah. It is common knowledge that within the Christian and Jewish telling of Abraham's sacrifice, the child is Isaac; however, within the Qur'an, there is a lack of specification. The contemporary idea is that it was Ishmael; however, early Muslim interpreters, like AlTabari, favored the idea that the son was actually Isaac and argued for him in his writings (Firestone 135). ${ }^{44}$ Be that as it may, there are numerous differences between the Qur'an's account and the Hebrew Bible's. The Jewish narrative has more detail; however, the biggest difference is the observation that Abraham actually attempted to sacrifice his son. In the Qur'an, Abraham did not have to physically attempt to sacrifice him; it was his submission to God and his intention to follow through with the command that proved to be enough.

\footnotetext{
${ }^{44}$ It is important to note references to Ishmael. Ishmael is mentioned in the Quran 10 times; however, 6 of these are outside of the narrative of Abraham in which he is placed in the broader context of other prophets (Noegel 155). The other three references place Ishmael in close proximity to Abraham, and in Q 14:35-41 Abraham is thanking God for granting Ishmael and Isaac as sons. The significance of this is that the narrative of Ishmael, and even including the type of connection he had with Abraham, is mostly found outside of the Qur'an in the writings and oral traditions of Islam.
} 
The last two major events discussed in the Qur'an concerning Abraham involves the building of the Ka'ba and the rite of Pilgrimage. Each of these significant events are not discussed in major detail in the Qur'an. The Ka'ba and the rite of Pilgrimage are significant because the site and the ritual that surrounds it is one of the most important/sacred concepts in Islam. For instance, the Ka'ba is where Muslims throughout the world direct their prayers. Most of the details surrounding the Ka'ba and the pilgrimage is found in the oral traditions of Islam. According to tradition, the sacred stone dates back to Adam and Eve in the Garden of Eden; it was the first sanctuary (Bearman). Also, according to tradition, it was hidden by God during the time when He flooded the earth; however, the Qur'an is not silent on the Ka'ba either. According to the sacred text, Abraham and Ishmael were instructed to build it (Q 2:123-127). The phrases "this sacred House" and "this ancient house" are used and never the word Ka'ba. However, it is assumed in Islam that these words are referring to the Ka'ba (Peters 17). ${ }^{45}$

Another important narrative found in the Qur'an concerning Abraham is the establishment of one of the pillars of Islam; the hajj or the pilgrimage. Q 22:27-30 it states:

"We showed Abraham the site of the House, saying, 'Do not assign partners to Me. Purify My House for those who circle around it, those who stand to pray, and those who bow and prostrate themselves. Proclaim the Pilgrimage to all people. They will come to you on foot and on every kind of swift mount, emerging from every deep mountain pass to attain benefits and celebrate God's name, on specified days, over the livestock He has provided for them - feed yourselves and the poor and unfortunate - so let the pilgrims perform their acts of cleansing, fulfil their vows, and circle around the Ancient House."”

\footnotetext{
${ }^{45}$ Concerning the Qur'an, there is not much further info on the Ka'ba, what is significant here is that Abraham is credited to building it.
} 
Here Abraham is seen as practicing the first hajj in history. The chief authority in this viewpoint is not a commentator but a historian named al-Azaraqi (d. 858). He describes Abraham as being the first person to perform the hajj and future Muslims emulated his actions (Peters 18).

As observed above, there are many elements of Abraham's narrative that seem to be left out. In other words, Abraham's account is very fragmentary. Before describing the narrative outside of the Qur'an it is important to discuss the origin of many of these stories. The early Muslims were surrounded by polytheists, Christians, and Jews. It is important to note though that there is little evidence of definite interaction with these groups of people. According to Jacob Lassner, he suggests that "if Mecca was a hub of international trade in the Prophet's lifetime, as most scholars believe, the inhabitants may very well have been subjected to foreign religious stimuli" (Lassner 131). And, if one supposes Muhammad, who accompanied caravans from Mecca to Syria-Palestine, there is another possibility he could have observed, as well as reported, both Christians and Jews in regard to their religious ideas and practice. Again, there is little evidence to suggest or deny that he had these interactions. The assumption continues though that naturally, through the many interactions that Muhammad and his followers may have had with these groups of people, there would have been a familiarity with these traditions. Consequently, if this did in fact take place, there is a possibility that the vast majority of the traditions of the prophets like David, Solomon, and Abraham which do not derive specifically from Hebrew or Christian scripture derive from the oral interpretation of these stories. Though there were translation of the canonical books of Judaism and Christianity in Arabic by the end of the eighth century, the majority of the people were 
illiterate and relied on oral transmission (Thackston xxvii). Still though, it is apparent that there are specific Islamic transmissions of these stories; thus, the vast majority of the legendary traditions go back to Abdullah ibn Salam (d. 663) and Kab al-Ahbar (d. 652), who were both learned Jewish converts to Islam (Thackston xiii). ${ }^{46}$ These factors and parallels are to significant to be reasonably explained as coming exclusively, or primarily, from non-Jewish sources (Stillman 13). Thus, since many of the stories in the Qur'an are fragmentary, the significance of these oral narratives served a dual purpose for early Muslims: satisfying a pious wish for elaboration on the cursory allusion to the prophets found in the Qur'an, and providing a form of entertainment for the masses (Thackston xiv).

There are an overabundance of orally transmitted stories of the prophets; this is even the case with Abraham as well. Therefore, there is one specific narrative that becomes important to this project. It is the extended story of Abraham's early life. ${ }^{47}$ According to Muslim tradition, Abraham lived in Mesopotamia under the reign of King Nimrod son of Canaan. Nimrod is not mentioned in the Qur'an by name; however, sura 2:158 places Abraham as debating with some Lord who ruled. Their argument concerned

\footnotetext{
${ }^{46}$ The debate concerning the origins of these stories still has not reached a consensus. At the same time that Thackston argues the Jewish origin, there are also theories that state these stories originated from the Christian tradition. They derived from monks, missionaries, and preachers. As noted in the beginning of this chapter, both Christian works and Jewish works were translated. Also, the Christians were more focused on missionary work then their Jewish counterpart. Be that as it may, it is the opinion of this writer that the majority of these stories derive from Jewish interpretations. As noted earlier, one of the chief sources that Muslims seem to use in regards to their oral narrative of Abraham is the Genesis Rabbah which was written in the $5^{\text {th }}$ century $\mathrm{C}$. There are numerous similarities between the two texts which will be seen below. The evidence is seen in the similarities between both the Jewish and Islamic narrative. These similarities involve both content and structure and it becomes difficult to disregard them.

${ }^{47}$ Earlier in the chapter, the story of Abraham and the smashing of idols was analyzed; however, within the oral tradition, there are numerous details that were left out. Also the significance of this story is that in regards to the numerous retellings, there are only a few variations.
} 
God's power to give life and death, and it is believed that this refers to Nimrod himself (Heller). In the Islamic narrative Nimrod was a king of great power who was tyrannical and even claimed godship (Thackston 132). He surrounded himself with soothsayers to teach him how to see the future and practice sorcery. He also promoted a man named Terah, one of his companions and his grand vizier; he was also an idol maker. ${ }^{48}$ One evening king Nimrod received a disturbing vision about a splendid star outshining a sun which his diviners interpreted as "One day soon a boy will be born in your kingdom who will rob you of the faith and respect of your people" (Knappert 72). The king tried to stop this by killing all the children; however, this ploy failed because Abraham was born in hiding. ${ }^{49}$ When he was a child, he was hidden in a cave and was sustained by sucking on his own fingers. "When he sucked his fingers, his thumb flowed with honey, his index finger with wine, his middle finger with milk, his ring finger with cream, and his little finger with water" (Thackston 138).

The early life of Abraham in the Islamic oral narrative follows along the same trajectory as the Qur'anic version. Abraham begins to discover God through logic and even through the study of the stars (Canan 19). Abraham also began to speak openly about the falsity of idols. He not only critiqued them but often would vandalize them in order to prove that these statues were not alive nor were they protected from any divine beings. This created a stir in the city and as a result people began to follow him and

\footnotetext{
${ }^{48}$ In Judaism, as well as this specific narrative, Terah is the father of Abraham. However, in the Qur'an the father of Abraham is called Azar. There is a debate within Islamic scholarship about who the father actually was. Does the narrative conflict with the Qur'an? Many commentators believe that these names are interchangeable or even that Azar is the Arabicized word for Terah (Sajjadi and Negahban)

${ }^{49}$ It is an interesting twist that in some narratives the father is Nimrod's most trusted person Terah, the chief architect of Idols (Thackston 134).
} 
believe in his God (Thackston 141). Consequent to this public disturbance, Nimrod called him to question him and prove his religious claims. As a result, Abraham did two astounding miracles, through the power of God, the first is that he resurrected Nimrods father long enough for him to say "Peace be upon you; listen to this young man and follow his advice for he is the chosen prophet of the One God" (Knappert 74). The second miracle was resurrecting four birds which were decapitated and cut to pieces. The blood and feathers were then mixed into one pile. Before Nimrod's very eyes, Abraham called upon God to bring them back to life and make them whole again (Thackston 143).

The king allowed him to leave in peace; however, Abraham found himself in trouble again when he destroyed the idols in the temple..$^{50}$ There was a large group that wanted him to be burned alive; Nimrod consented to their wishes (Thackston 147). Therefore, he was placed on the pyre and burnt alive; however, just like the narrative in the Qur'an, the fire did not burn him because God commanded it to "be cold" (Knappert 75). Abraham was in the fire for seven full days and survived because God sustained him with food from heaven and even a well of water. Thus, Abraham was delivered from the flames miraculously.

This narrative of Abraham's early life is important because there is another strong parallel; the Genesis Rabbah $\left(5^{\text {th }}\right.$ century C. E.) found in Judaism are very similar in regards to the plot as well as even the details. In some cases, these stories are identical concerning the latter. The plot found in the Genesis Rabbah has Abraham born in secret in a cave because the king is hunting to kill him (Ginzberg 187). The reason for the

\footnotetext{
${ }^{50}$ We mentioned this story prior to this because we also find it in the Qur'an; however, the oral tradition adds more detail especially concerning the punishment the king decreed for his crime.
} 
sought after death of the babe is that there was a sign written in the stars that someone would rise up against him and destroy the false religion that the king proclaimed. When Abraham became older he started to preach against the false religion that the people held. He claimed that the king was only a man and that "the Eternal, He is the One Only God, and there is none besides" (Ginzberg 193). Abraham continued to preach to the people in this way and he began to gain a following. Just as the Islamic version, Abraham is arrested after he destroys the idols of the gods and an idol of King Nimrod which the people worshiped and revered. The king threw him in the fire; however, God delivered him from being consumed by flames.

The similarities between the plots strongly suggest that the Islamic narrative of Abraham is dependent on the Genesis Rabbah, especially in regards to Abraham. The evidence is further confirmed by the remarkably similar details between the two sources. There are three specific details that make the case very compelling. The first is that Abraham was sustained himself by sucking his fingers. In the Islamic account, each finger produced a different fluid. This same detail is also found within Jewish tradition; however the only difference is that milk was the only fluid that flowed from his fingers (Ginzberg 189). The second detail revolves around the identity of the king. In both versions of the story, the king is Nimrod son of Canaan; he was a studied astrologer and could read signs from the heavens. In both the Islamic and Jewish accounts, he discovered that there would be an individual who would ruin his reign. He also claims godship and commands his people to worship him. The third detail worth mentioning is how God saved Abraham from the fire. In the Islamic narrative, God commanded the 
flames to "be cold"; likewise, in the Genesis Rabbah, God tells the fire to "Cool off" (Ginzberg 201).

It would be misguided to not note that not all details match up. There are elements in both stories that differ exponentially. For instance, in the Islamic narrative, Sarah, the wife of Abraham, is Nimrod's own daughter. She becomes attracted to Abraham and the truth of his message. This detail is not found in the Jewish counterpart. Also, the length of the burning differs; in the Islamic version, Abraham sits in the fire for seven days, while it is an unspecified time in Judaism. With the differences in mind, it still seems that there is a unique similarity that can only be explained if there was a borrowing from one of the stories. In retrospect of both the Qur'anic similarities and the similarities found in the Genesis Rabbah concerning Abraham, it appears that the originally Jewish narrative was told from an Islamic perspective.

\section{Abraham as the Embodiment of Muhammad's Message}

As stated earlier, the Qur'an appeals to Abraham in such a way that draws a similarity between Islam and the religion that the Prophet Muhammad preached. The revelation of Muhammad may even be seen as a return to the original religion of God. Q 16:123 it states: "Then we revealed to you [Muhammad], 'Follow the creed of Abraham, a man of pure faith who was not an idolater.",51 Again Q 6:161 states; "Say, 'My Lord has guided me to a straight path, an upright religion, the faith of Abraham, a man of pure faith. He was not a polytheist." These verses suggest that Muhammad is following the same religion as Abraham; consequently Muslims understand that this religion was given

\footnotetext{
${ }^{51}$ Further on in this chapter, the investigation of Abraham's qualities will take place. Prior to doing this, it is important to discuss the actual narrative first.
} 
to them. The religion of Abraham is connected to the message, preaching, and teaching of Muhammad (Tottoli 10). ${ }^{52}$ Thus, Abraham embodies key aspects of the Muslim faith.

There are many concepts in Islam that is exemplified through Abraham's character; however, one of the most important ones is that of the hanif. The hanif is someone that is neither a Jew, a Christian, nor a polytheist; in actuality, the hanif predates all of these groups of people. ${ }^{53}$ It also refers to the turning away from idolatry to worshiping the one true God (Rubin, 403). The word hanif comes from the root hanaf, which means "going from deviance to soundness, from crookedness to straightness, from misguidances to truth" (Canan 29). The Qur'anic prototype of the hanif is Abraham. Q 3:67-68 states "Abraham was neither a Jew nor a Christian. He was upright and devoted to God, never an idolater, and the people who are closest to him are those who truly follow his way."

Abraham was a monotheist; therefore, as the oral narratives above suggested, he did not associate any partners with God. This idea can be found in the term tawhid which is faith in the Oneness of God. This is of one of the 5 pillars of Islam, the Shahada which is the declaration of faith in God's oneness (Ghamidi Loc 441). The doctrine was one of the first lessons bestowed to mankind and this idea is often derived from Q 7:172-73 (Mir 161) ${ }^{54}$ However, it is interesting to note that Abraham had a very high degree of

\footnotetext{
${ }^{52}$ Another verse from sura 22:78 suggests this when it states "Strive hard for God as is His due: He has chosen you and placed no hardship in your religion, the faith of your forefather Abraham."

${ }^{53}$ Christians and Jews are seen as distorting the original monotheism (See beginning of chapter).

${ }^{54}$ Q 7:172-173 states; "[Prophet], when your Lord took out the offspring from the loins of the Children of Adam and made them bear witness about themselves, He said, 'Am I not your Lord?' and they replied, 'Yes, we bear witness.' So you cannot say on the Day of Resurrection, 'We were not aware of this,' or, 'It was our forefathers who, before us, ascribed partners to God, and we are only the descendants who came after them: will you destroy us because of falsehoods they invented?'
} 
tawhid. It can be said that tawhid is an awareness of God's oneness and this is consistently hinted at within the Quran as well as the traditions associated with Abraham (Canan 23). Tawhid can be influenced by having doubt or to a greater part shirk which is defined as associating partners with God. The issue with both Jews and Christians is that they were once considered on the right path to God and had tawhid; however, they slowly turned away from the belief in God's oneness and began to get confused. The level of tawhid decreased over time. This never happened to Abraham; on the contrary, Abraham constantly spoke out against shirk and any other form of disbelief.

Another quality that is important in Islam is submitting oneself to God. In fact, what makes someone a true believer or mu'min is this very characteristic (Ghamidi Loc 549). Sura 2:131 states "His Lord said to him (Abraham), 'Devote (submit) yourself to Me.' Abraham replied, 'I devote myself to the Lord of the Universe.'” This can once again be seen by revisiting the narratives. There are two specific instances that are mentioned above, which are worth noting again in regards to Abraham's submission: the sacrifice of his son and the destruction of the idols. When he received the vision to sacrifice his son, he submitted to God without question. Likewise, when he was in the hostile territory of Nimrod, he did not falter in his tawhid nor his submission. The result of his obedience was the attempt by Nimrod to burn him alive.

The last quality worth mentioning is Abraham's compassion and mercy. These two characteristics are very important in Islam; it revolves around the moral of kindness or ihsan (Ghamidi Loc 1051). Ihsan helps develop a society or a community around love, sympathy, compassion, sincerity, gratitude, and magnanimity. Virtually more than any other prophet in Islam, did Abraham represent this. Within the Qur'an, Abraham is seen 
in at least two occasions as praying on behalf of others. Sura 14:41 Abraham states, "Our Lord, forgive me, my parents, and the believers on the Day of Reckoning." There are not many prophets who have this level of compassion and mercy. Moses as well as Noah prayed for punishment on those who they regarded as their enemies (Canan 42). Even when people were persecuting him, Abraham still did not call on God to curse them.

\section{Conclusion}

Abraham is a unique character among the prophets of Islam. He was the original hanif and spread his monotheism among the people of his day. The Qur'an calls not only for Muslims, but also Christians and Jews to emulate him. The sacred text challenges the other Abrahamic faiths to stop squabbling over differences and look back at the religion Abraham really had. According to the Qur'an, if the challenge is accepted, it will reveal that Abraham did not follow the practices of the Jews or the Christians; on the contrary, his religion resembles that which Muhammad preached. Essentially, Abraham is used as a proof of Muhammad's message.

Another interesting element in regards to Abraham is the reference regarding him in both the Qur'an and the Genesis Rabbah. It would appear that Islam took the narrative of Abraham from the Jewish context and Islamized it. This seems to have been used as a tool to prove the truth claim of Muhammad in the backdrop of both Christianity and Judaism. Therefore, the reference to Abraham was a strategy to prove that the message of Muhammad did not necessarily supersede the other Abrahamic faiths but was a return to the original plan that God intended. Just as Michael Lodahl stated in his work, Claiming Abraham, Islam cleans up the images and complexities that the former tradition (Judaism) held. Therefore, it is no surprise that there are striking similarities between the 
narratives, both in the Qur'an and the oral tradition, concerning Abraham in Judaism as well as Islam. 


\section{SAME ROADS TO THE SAME CONCLUSION}

The term 'Abrahamic religions' is loaded with meaning. Often, it is used to show that the three Abrahamic religions: Judaism, Christianity, and Islam, are very similar. This is especially true for people who promote interfaith dialogue. However, be that as it may, it is not exactly a perfect term. There are numerous concepts upon which the religions do not agree.

For example, while each of these religions highlight the themes of faith, righteousness, and obedience in their telling of the story of Abraham, they use these terms to make very different points theologically. Thus, in chapter 3 , we examined Michael Lodahl comparison of the story of Isaac's birth found in both the Bible and the Qur'an. He places them side by side and shows that each story has major theological differences. One significant difference between the two stories is the identity of the visitors. The Qur'an states that they were messengers while the book of Genesis uses the tetragrammaton which is understood as the name of God. This adds a major dilemma in Jewish as well as Christian exegesis; did God really come down to visit Abraham? According to Lodahl, this is one aspect of the story in which the Qur'anic narrative seems to be attempting to 'clean up' this dilemma which surrounds the Divine. (Lodahl 17). The story of Lot was also mentioned. In Christianity and Judaism it is taught from scripture that Lot impregnated his daughters (Genesis 19:30-38). Even Noah did some questionable things with his son when he got drunk after the flood (Genesis 9:21). Each of these stories finds no comparison in the Islamic narrative because these individuals were prophets; consequently, these are not actions that prophets would commit. This is not to state that prophets were free from error; the only Prophet given such a status was 
Muhammad. However, these types of mistakes are extremely taboo and a prophet of God, even the imperfect ones, would never commit such actions.

Though there are major difference between the three Abrahamic religions, especially between Christianity and Islam, there is also interesting similarities that this project reveals. Both of these religions echo supersessionism in each of their sacred texts and narratives concerning their Jewish counterpart. This becomes apparent during the observation of Abraham. In regards to the patriarch, Christianity and Islam both use very similar avenues to claim him. Each of these faiths do at least three identical things: they each go back to either Jewish scripture or tradition to claim him, they use Abraham to prove their truth claims, and they each essentially claim to be the true religion of Abraham. ${ }^{55}$

\section{Sharing Scripture with their Jewish Counterpart}

The discourse in both Christianity and Islam share the similarity of relying on Jewish written and oral tradition to claim Abraham. Christianity referred to Jewish scripture numerous times in regards to Abraham. For this group, it was especially important to do this because the audience they were attempting to reach were the Jews. Matthew and Paul both rely on Jewish scripture to reach a Jewish audience. For instance, the Gospel of Matthew has the most references to Jewish scripture than any other of the synoptic Gospels (Plummer xxxiii-xxxvi). In the genealogy of Matthew, the author made it clear as well that Jesus was a descendent of Abraham. For Matthew, showing this reveals that Jesus was Jewish. On the other hand, Paul in his Galatians letter, used

\footnotetext{
${ }^{55}$ It has been noted earlier that Islam never specifically quotes Hebrew scripture; however, this project, during the third chapter, have analyzed very similar stories that are both found in the Qur'an and Genesis. For instance, the investigation of the visit of the messengers was previously discussed.
} 
scripture to combat the idea that a new believer has to be circumcised and follow the Jewish law. It is important to stress that the Christian movement was essentially a Jewish one from the very beginning; therefore, it was a significant task to not only prove their claims but show it with the use of Jewish scripture. The author of Mathew, Acts, and the writings of Paul used this strategy very heavily.

The writings of Paul as well as the speeches found in Acts, more so then Matthew, share many verses in the Torah which surround the Biblical character of Abraham. As a matter of fact, they actually take direct references from Hebrew Scripture. For instance, Paul, in Galatians 3 quotes Genesis 15:6 verbatim. ${ }^{56}$ He does the same thing again in Galatians chapter 3 by combining two verses: Genesis 12:3 and Genesis 18:18. ${ }^{57}$ Again, Paul follows a similar pattern during his letter to the Romans. In Romans 4:18 he states "as it is written, 'I have made you the father of many nations'-in the presence of the God in whom he believed against hope, that he should become the father of many nations, as he had been told, 'so shall your offspring be." This is a quote taken from Genesis 15:7. Acts also refers to direct quotes from the Torah as well in regard to Abraham. In chapter 3 as well as chapter 7, the author of Acts has both Peter and Stephen quoting the promises God made to Abraham in Genesis 15:14. It is apparent that Christianity shares scripture with their Jewish counterparts and it is not surprising because the infancy of the early Church was a Jewish movement. However, these doctrines began replacing or superseding their Jewish counterpart. The prior Jewish outlooks were regarded as misinterpretations.

\footnotetext{
${ }^{56}$ Genesis 15:3 states "And he believed the LORD, and he counted to him as righteousness."

${ }^{57}$ See Chapter 2.
} 
It is interesting to see Islam follow the same route as Christianity. In the beginning of chapter 3, it was mentioned how the religion of Islam regards both Christianity and Judaism as corrupted. The message they each preach is not the message God originally intended. Even though this is the case, like Christianity, Islam shares stories and traditions with Judaism as well. Therefore, the revelation of Muhammad also superseded not only the corrupted Jewish revelation, but the Christian one as well.

There are two stories in particular that Islam shares with Judaism. The first story is found in three different suras: 21, 26, and 37. Each of these Qur'anic passages places Abraham at odds with polytheists. He argues against the logic of having multiple gods as well as praying to statues. Also in this story, Abraham breaks the idols and gets thrown into a fire; he is then delivered from the heat of these flames. This narrative is also found in Judaism; however, the story derives from the Genesis Rabbah and not the Torah. The Jewish version of the story has virtually the same plot as the Qur'an. According to scholars such as W. M. Thackston and Reuven Firestone, the vast Jewish traditions that included Abraham go back to the early Jewish converts such as Abdullah ibn Salam (d. 663) and Kab al-Ahbar (d. 652) (Thackston xiii). In each version of the story there are key details that are too similar to disregard. One such example that was mentioned in chapter 3 concerns the time when Abraham was hiding in a cave. His mother placed him there for fear of the king (Nimrod) attempting to kill him. During this time in the cave, Abraham would suck his fingers for sustenance. Though the Islamic story has more details on what flowed from his fingers (milk, honey, water, etc.), the stories show a clear similarity. 


\section{Using Abraham to prove Truth Claims}

Concerning the sharing that both Christianity and Islam had with Judaism, it is important to reiterate the purpose of this process. The examples explored above are only a few of the numerous instances that these religions share with their Jewish counterpart; however, the rationale was in order to prove their truth claims. Throughout the Bible and the Qur'an (as well as the oral traditions), Abraham is used in a way that he represents the embodiment of each of these faiths. In the Christian and Islamic perspectives, Abraham was not Jewish but the progenitor or their traditions. In other words, for the Christian, Abraham resembles more of their faith, while for the Muslim, Abraham was actually the first Muslim.

Paul and the author of Acts use Abraham and the elements in his story in order to prove Gentile inclusion. The transition from Christianity being a Jewish movement to one that can stand on its own was a long process. Therefore, it was important for early Christian writers to show from scripture that what they were doing was correct and from God. Their message superseded that of Jewish teaching; however, the early Christians needed to prove this. Abraham was a useful tool in this regard. Essentially, each author took passages from the Torah and reinterpreted them. Paul, for instance in his letter to the Galatians, distances the Jews from being heirs to Abraham. ${ }^{58}$ He refers to Genesis 15:6

\footnotetext{
${ }^{58}$ It is important to note here that Paul and the early Church, did not see themselves as a separate movement from Judaism. Consequently, supersession did not mean for Paul that the Jew's were replaced by gentiles or their covenant was replaced. Paul states in Romans 9:4-5; "They are Israelites, and to them belong the adoption, the glory, the covenants, the giving of the law, the worship, and the promises." Also Paul states in Romans 11:1-5: "I ask, then, has God rejected his people? By no means! For I myself am an Israelite, a descendant of Abraham, a member of the tribe of Benjamin. God has not rejected his people whom he foreknew. Do you not know what the Scripture says of Elijah, how he appeals to God against Israel? 'Lord, they have killed your prophets, they have demolished your altars, and I alone am left, and they seek my life.' But what is God's reply to him? "I have kept for myself seven thousand men who have
} 
which states "And he believed the LORD, and he counted to him as righteousness." Here Paul was using a statement about Abraham to critique the common idea that Jews had concerning righteousness. It was not through works nor heritage that one was a descendent of Abraham; it was a matter of faith. Abraham was a man of righteousness and obedience; however, according to Paul and the author of Acts it was about his faith and not his deeds that made him righteous.

The Gospel of John also appeals to Abraham to prove not only that physical heritage from Abraham was meaningless, but that being a descendent doesn't necessarily mean an inheritance of the promise. In John 8, the author pits Jesus against the religious leaders. As stated in chapter 2, in the context of this passage, the religious leaders were plotting to kill Jesus. Therefore, when they claimed that they were children of Abraham, Jesus replied that they were actually children of the Devil (John 8:44). In Jesus' view, children emulate the father; therefore, the religious leaders were not true children of Abraham because they are not emulating him. Abraham would never attempt to kill Jesus. Only the Devil sought that out. ${ }^{59}$

The religion of Islam was no different in regards to the use of Abraham. Throughout the Qur'an and the oral traditions of the faith, Abraham was used to argue that he was the embodiment of the message of Muhammad; he proved the Islamic worldview. Sura 2:135 states; "They say, 'Become Jews or Christians, and you will be rightly guided.' Say [Prophet], 'No, [ours is] the religion of Abraham, the upright, who did not worship any god besides God.' Chapter 3 discussed that Abraham represented

\footnotetext{
not bowed the knee to Baal." So too at the present time there is a remnant, chosen by grace. Paul was an Israelite, he did not have an issue with the Jewish people, and he believed they misinterpreted scripture.

${ }^{59}$ For more information regarding how Abraham proved Christian truth claims see chapter 2.
} 
important qualities that a Muslim should have and hope to attain. The most important quality was that of tawhid (faith in the oneness of God). Abraham had such a profound level of tawhid that there was no amount of doubt or unbelief in him whatsoever. In every narrative in which the prophet Abraham is found, he never struggles with his belief nor falls into temptation of associating partners with God. Another important characteristic in Islam is submitting to the will of God. Abraham also exemplifies this to an extreme. In each narrative of Abraham, he always follows what God commands. When he received a vision to sacrifice his son, he submitted to God's will and was willing to obey without hesitation. This characteristic can also be seen during his early life in Mesopotamia while Nimrod son of Canaan reigned. Abraham refused to falter in his obedience even when it meant that he would be thrown into a fire.

There is one last observation worth noting in regards to Islam and Abraham being an embodiment of it. Though it does not testify to a specific quality of Islam, Abraham does represent two important elements of the religion. Abraham is accredited with the rebuilding of the Ka'ba which is the sacred site of Islam. He built it with his son Ishmael. It is not only building the Ka'ba, but even the hajj which is the pilgrimage to this holy site is accredited to being started by him. This is one strategy in which Islam claims to have the true religion of Abraham and it is a proof that Muhammad did not inherit his tradition from the Jews. Therefore, with regards to both certain characteristics as well as rituals found in Islam, Abraham becomes the exemplar of Islam within this religious tradition. 


\section{The Original Religion of Abraham}

The final aspect that both Christianity and Islam share is that they each claim to be the original religion of Abraham. This is another element of the supersession discourse. As noted in chapter 3, Islam states that the revelation of Muhammad is the original religion of Abraham explicitly. Muhammad was a follower of the Abrahamic faith; however, on the other hand, Christianity does not state it in such plain terms. For Christianity, this conclusion develops by the constant referencing to Abraham throughout the New Testament. The followers of Jesus transformed the Jewish story of Abraham into an explicitly Christian one. They did this in numerous ways. One way was by referring to Abraham's faith. As noted in chapter 2, Paul in Galatians makes a statement that the Christian faith actually is a closer representation to Abraham then the Jewish perspective. Also in John 8, the author uses Jesus to say that Abraham would essentially believe in the message that Jesus was speaking. Consequently, these examples, as well as the ones mentioned in chapter 2 reveal an appeal to Abraham in such a way as to allude that if Abraham were actually alive, he would side with Jesus and his followers.

\section{Implications and Future Research}

The implications of this study are immense. This project stresses that both Christianity and Islam inherit Abraham by very similar means. In a society where there are numerous conflicts based on religious ideals, this research is important. It is a misguided notion to state that Christianity and Islam are more alike than different because there are too many inconsistencies with their theology. The Qur'an for instance states that the Jews and the Christians are misguided and have been led astray. This is an exclusivist statement. On the other hand, there are clear exclusivist statements in the New 
Testament which talk about the only way to God is being though Jesus. It is very difficult to ignore and rationalize statements like these.

Therefore, this type of research opens the door to investigate the evolution of these thoughts, for instance, supersession. Christianity and Islam each have an idea of superseding Judaism. Christianity received a New Covenant through Jesus while Islam went back to the original religion that God intended. This research places both of these religions side by side, and with the context of Abraham, they each took similar roads to claim him. Thus, taking concepts of each of these religions and comparing them together, even though they may be different theologically, may show a new similarity between Christianity and Islam. For instance, a future prospect that could be compared with each other is the development of how God reacts with humanity. Islam and Christianity both have different ideas in this regard. Michael Lodahl suggests this in his comparison with the proclamation of Isaacs's birth in both Jewish Scripture and the Qur'an; however, comparing them side by side may show that they develop their conclusions by similar venues. It may open a new door for dialogue and help with the realization that these faiths are more alike than different especially in regards to their development. 
Bibliography

Asad, Muhammad. The message of the Qur'an : the full account of the revealed Arabic text accompanied by parallel transliteration. Bitton: Book Foundation, 2003.

Barnes, Albert. Notes on the New Testament. Ed. Robert Frew. Blackie \& Son. London, n.d. PC Study Bible.

Barrett, C. K. From First Adam to Last Adam. London: Charles and Black, 1962.

P. Bearman, "Ka ba." Encyclopaedia of Islam, Second Edition. Edited by: Th. Bianquis, C.E. Bosworth, E. van Donzel, W.P. Heinrichs. Brill Online, 2014. Reference. Florida International University (FIU). 12 May 2014 $<$ http://referenceworks.brillonline.com/entries/encyclopaedia-of-islam-2/kabaCOM_0401>

Brawley, Robert L. Luke-Acts and the Jews: Conflict, Apology, and Conciliatation. Atlanta : Scholars Press, 1987.

Brown, Raymond E. The Birth of the Messiah: A Commentary on the Infancy Narratives in the Gospels of Matthew and Luke. New York: Doubleday, 1993.

Bruce, F. F. The Book of Acts. Grand Rapids : Erdmans, 1988.

Canan, Ibrahim. The Message of Abraham: His Life, Virtues, and Mission. Trans. Jessica Ozalp. Somerset: The Light Inc., 2007.

Dodd, C. H. The Interpretation of the Fourth Gospel. Cambridge: Cambridge University Press, 1953.

Doukhan, Jacques. Drinking at the Sources. Mountain View: Mountain Press Publishing Association, 1981.

Feiler, Bruce S. Abraham: A Journey to the Heart of Three Faiths. New York: W. Morrow, 2002.

Firestone, Reuven. Journeys in Holyd Lands: The Evolution of the Abraham-Ishmael Legends in Islamic Exegesis. Albany: State University of New York, 1990. 
Ghamidi, Javed Ahmad. Islam: A Concise Introduction. Trans. Shehzad Saleem. Lahore: Al-Mawid, 2012. Kindle Edition.

Ginzberg, Louis. The Legends of the Jews. Trans. Henrietta Szold. Vol. 1. Philadelphia: The Jewish Publication Society of America, 2007. 7 vols.

Haenchen, Ernst. The Acts of the Apostles: A Commentary. Philadelphia: The Westminster Press, 1971.

Hansen, G. Walter. Abraham in Galatians: Epistolary and rhetorical contexts. Sheffield: JSOT, 1989.

Hare, Douglass R. A. The Theme of Jewish Persecution of Christians in the Gospel According to St. Matthew. Cambridge : Cambridge University Press, 1967.

Heller, B. "Namrūd." Encyclopaedia of Islam, Second Edition. Edited by: P. Bearman, Th. Bianquis, C.E. Bosworth, E. van Donzel, W.P. Heinrichs. Brill Online, 2014. Reference. Florida International University (FIU). 11 July 2014 http://referenceworks.brillonline.com/entries/encyclopaedia-of-islam-2/namrudSIM_5791

Herford, R. Travers. Judaism in the New Testament Period. London: Lindsey Press, 1928.

Herr, Moshe David, and Stephen G. Wald. "Genesis Rabbah." Encyclopaedia Judaica. Ed. Michael Berenbaum and Fred Skolnik. 2nd ed. Vol. 7. Detroit: Macmillan Reference USA, 2007. 448-449. Gale Virtual Reference Library. Web. 12 July 2014.

Jeremias, Joachim. The Central Message of the New Testament. New York: Charles Scribner's Sons, 1965.

Jocz, Jacob. The Jewish People and Jesus Christ. Grand Rapids: Baker House, 1979.

Juster, Daniel. Jewish Roots. Rockville: Davar, 1986.

Keener, Craig S. The IVP Background Commentary: New Testament. Madison, 1993. PC Study Bible v.5. 
Kilgallen, John. The Stephen Speech: A Literary and Redactional Study of Acts 7,2-53. Rome: Biblical Institute Press, 1976.

Knappert, Jan. Islamic Legends: Histories of the Heroes, Saints and Prophets of Islam. Vol. I. Leiden: E. J. Brill, 1985.

Lassner, Jacob. Jews, Christians, and the Abode of Islam. Chicago: The University of Chicago Press, 2012.

Lazarus-Yafeh, Hava. "Tahrīif." Encyclopaedia of Islam. Second Edition. Ed. P Bearman, et al. Comp. Florida International University. Brill Online, 2012. 30 April 2014. $<$ http://referenceworks.brillonline.com/entries/encyclopaedia-of-islam-2/tahrifSIM_7317>.

Levenson, Jon D. Inheriting Abraham: The Legacy of the Patriarch in Judaism, Christiantiy, and Islam. Princeton: Princeton University Press, 2012.

Lodahl, Michael. Claiming Abraham: Reading the Bible and the Qur'an Side by Side. Grad Rapids: Brazos Press, 2010.

Mir, Mustansir. "Polytheism and Atheism." Encyclopaedia of the Qur'an. Ed. Jane Dammen McAuliffe. Vol. 4. Leiden, The Netherlands: Brill Academic Publishers, 2004. 158-162. Gale Virtual Reference Library. Web. 11 July 2014.

Moberly, R. W. L. The Theology of the Book of Gensis. Cambridge: Cambridge University Press, 2009.

Moxnes, Halvor. Theology in Conflict: Studies in Paul's Understanding of Romans. Leiden: E. J. Brill, 1980.

Musavi Lari, Sayyid Mujtaba. The Seal of the Prophets and His Message. Trans. Hamid Algar. Potomac: Islamic Education Center, 2005.

Noegel, Scott B. Historical Dictionary of Prophets in Islam and Judaism. Lanham: Scarecrow, 2002.

Peters, F. E. Islam: A Guide for Jews and Christians. Princeton: Princeton University Press, 2003. 
Plummer, Rev. Alfred. A Critical and Exegetical Commentary on on the Gospel According to S. Luke. Ed. Rev. Samuel Rolles Driver and Rev. Charles Augustus Briggs. Fith Edition . Edinburgh: T. \& T. Clark Ltd, 1981.

Rabinoqitz, Louis Isaac and Max Eichhorn David. "Proselytes." Encyclopaedia Judaica 16 (2007): 587-594. Gale Virtual Reference Library. Web. March 2014.

Richardson, Peter. Israel in the Aposolic Chuch. Cambridge: Cambridge University Press, 1969.

Rif'at, Nurshīf 'Abd Al-Rabīm Mustafa. Ibn Hazm On Jews and Judasim. University of Exester. 1988.

Rippin, Andrew. Muslims: Their Religious Beliefs and Practices. 3rd. New York: Routledge, 2005.

Rubin, Uri. "Hanīf." Encyclopedia of the Qur'an. Ed. Jane Dammen McAuliffe. Vol. 2. Leiden, The Netherlands: Brill Academic Publishers, 2002. 402-404. Gale Virtual Reference Library. Web. 29 Apr. 2014.

Sajjadi, Sadeq; Negahban, Farzin. "Abraham." Encyclopaedia Islamica. Editors-in-Chief: Wilferd Madelung and, Farhad Daftary. Brill Online, 2014. Reference. Florida International University (FIU). 29 April 2014 $<$ http://referenceworks.brillonline.com/entries/encyclopaedia-islamica/abrahamCOM_0028>

Schiffman, Lawrence H. Reclaiming the Dead Sea Scrolls. New York: The Anchor Bible Reference Library, 1995.

Schnackenburg, Rudolf. The Gospel According to Sr. John. Vol. II. New York: The Seabury Press, 1971.

Schoville, Keith. Biblical Archaeology in Focus. Grand Rapids: Baker House, 1978.

Shtober, Shimon. "Present at the Dawn of Islam: Poleic and Reality in the Medieval Story of Muhammad's Jewish Companions." Laskier, Michael M. and Yaacov Lev. The Convergence of Judaism and Islam: Religious, Scientific, and Cultural Dimensions. Gainsville: University Press of Florida, 2011. 64-88. 
Siker, Jeffrey S. Disinheriting the Jews: Abraham in Early Christian Controversy. Louisville: Westminster/John Knox Press, 1991.

Stillman, Norman A. "Judaism and Islam: Fourteen Hundred Years of Intertwinned Destiny? An Overview." Laskier, Michael M. and Yaacov Lev. The Convergence of Judaism and Islam: Religious, Scientific, and Cultural Dimensions. Gainseville: University Press of Florida, 2011. 10-23.

Thackston, W. M. JR. The Tales of the Prophets of al-Kisa'i. Vol. II. Boston: Twayne Publishers, 1978.

Tottoli, Roberto. Biblical Prophets in the Quran and Muslim Literature. Richmond: Curzon Press, 2002.

Vermes, Geza. Jesus and the World of Judaism. Philadelphia : Hermon Press, 1984.

Whitacre, Rodney A. Johannine Polemic: The Role of Tradition and Theology. Cambridge: Society of Biblical Literature, 1982.

Wilson, Marvin R. Our Father Abraham: Jewish Roots of the Christian Faith. Grand Rapids: Erdmans Publishing Company, 1889.

Walvoord, John F. Bible Knowledge Commentary. Vol. I. Ed. Roy B. Zuck. 1983. PC Bible Study v5. 15 April 2014. 